\title{
Review \\ When Blockchain Meets the AEC Industry: Present Status, Benefits, Challenges, and Future Research Opportunities
}

\author{
Mengyuan Cheng, Guoliang Liu *, Yongshun Xu and Ming Chi
}

School of Management, Jilin University, Changchun 130012, China; mengyuancheng1995@163.com (M.C.); xys8023cm@163.com (Y.X.); amry1991@163.com (M.C.)

* Correspondence: glliug@jlu.edu.cn

Citation: Cheng, M.; Liu, G.; Xu, Y.; Chi, M. When Blockchain Meets the AEC Industry: Present Status, Benefits, Challenges, and Future Research Opportunities. Buildings 2021, 11, 340. https://doi.org/ 10.3390 /buildings 11080340

Academic Editor: Pierfrancesco De Paola

Received: 4 July 2021

Accepted: 5 August 2021

Published: 6 August 2021

Publisher's Note: MDPI stays neutral with regard to jurisdictional claims in published maps and institutional affiliations.

Copyright: (c) 2021 by the authors. Licensee MDPI, Basel, Switzerland. This article is an open access article distributed under the terms and conditions of the Creative Commons Attribution (CC BY) license (https:// creativecommons.org/licenses/by/ $4.0 /)$.

\begin{abstract}
Blockchain is regarded as a potential technology for transforming the architecture, engineering, and construction (AEC) industry, and the number of related publications is increasing rapidly. However, a systematic review of blockchain applications in the AEC industry is lacking. The objective of this study was to review the current status of blockchain applications via a bibliometric analysis combined with a systematic literature review. According to related articles collected from databases, the present status of blockchain was analysed with regard to the distribution of articles over publication years, journals, institutions, countries, cooperation networks between authors, keyword co-occurrence networks, and research methodologies. The results indicated that research on blockchain applications is still relatively new and fragmented with regard to several topics. Five areas of benefit were identified: (i) supply chain management, (ii) contract management, (iii) information management, (iv) stakeholder management, and (v) integration management. On the basis of the technology-organisation-environment framework, nine types of challenges were identified. Future research opportunities were proposed according to the research findings. This study contributes to the current body of knowledge and provides guidelines for further research on blockchain applications in the AEC industry.
\end{abstract}

Keywords: blockchain; AEC industry; benefits; challenges

\section{Introduction}

The architecture, engineering, and construction (AEC) industry is facing unprecedented challenges with the increasing investment scale, uncertainty, and complexity of such projects. Poor communication, information sharing, and workflow control among participants are the major challenges faced by the AEC industry, which cause low efficiency and poor performance [1-3]. Blockchain technology has potential for transforming the conventional AEC industry [4,5] and thus may be useful for solving these issues. Blockchain enhances the traceability, transparency, and accountability of business processes during the project lifecycle, improving information sharing, enhancing transparency, and addressing trust problems [6,7].

Blockchain has received increased interest from AEC researchers because of its potential benefits. For example, smart contracts are being deployed to facilitate payment security [8]. Novel blockchains are being used to solve information gaps in the construction supply chain [7]. Blockchain has been integrated with the building information model (BIM) to improve the BIM working environment $[9,10]$. However, the AEC industry still lags behind other industries [11]. To improve blockchain adoption in the AEC industry, researchers must present AEC practitioners with a comprehensive review of blockchain applications - particularly the potential benefits and challenges. There is a limited understanding of blockchain applications in the AEC industry.

Blockchain applications in the AEC industry have been reviewed in previous works. Wang et al. [12] and Dakhli et al. [13] described the potential applications of blockchain in the construction sector. San et al. [14] identified the potential uses and implications of 
blockchain applications in the construction industry. Yang et al. [11] illustrated the process, benefits, and challenges of adopting private and public blockchains in the construction domain through a pilot study. Although these studies enhance our understanding of blockchain applications in the AEC industry, few rigorous and empirical academic studies have been performed on the benefits and challenges of blockchain. Perera et al. [15] summarised the potential applications and challenges of blockchain applications in the construction industry and confirmed blockchain indeed has a credible potential in the construction industry. Li et al. [4] conducted a systematic review of the use of blockchain in built environments and compiled an extensive list of challenges and opportunities presented by blockchain across four dimensions (technical, process, policy, and social). These two studies reviewed blockchain in construction as a whole. However, with the rapid development of blockchain in recent years, related research has been published but remains in a fragmented state. Additionally, previous research lacks a review of the potential advantages, challenges, and future research opportunities. Therefore, on the basis of previous studies, a mixed-method approach of bibliometric analysis and systematic review was adopted to investigate the research on blockchain applications in the AEC industry for answering the following research questions (RQs):

RQ1. What is the present status of blockchain applications in the AEC industry?

RQ2. What are the benefits of blockchain applications in the AEC industry?

RQ3. What are the challenges of blockchain applications in the AEC industry?

The objectives of this study were to (i) identify the knowledge base regarding blockchain applications in the AEC industry, e.g., information on related journals, institutions, authors, and keywords; (ii) identify the benefits of blockchain applications in the AEC industry; and (iii) identify the challenges of blockchain applications in the AEC industry. According to these objectives, future research directions for the topic were also analysed. These goals were achieved through three phases of research. The first was a bibliometric search of the literature, followed by a quantitative analysis for constructing science maps. Finally, a content analysis was conducted by presenting the benefits and challenges of blockchain applications in the AEC industry.

The remainder of this paper is organised as follows. Section 2 describes the research methodology and the results are presented in Sections 3 and 4 . Sections 5 and 6 present a discussion of the results and an outline of future research opportunities, respectively. Finally, the conclusions and research limitations are summarised in Section 7.

\section{Research Methodology}

A bibliometric analysis combined with a systematic review was employed to map and analyse existing knowledge regarding blockchain applications in the AEC industry. Bibliometric analysis refers to the use of statistical methods to measure the quality and quantity of publications. Quantitative bibliometric tools describe the development of scientific knowledge in a field [16] and are important for analysing and predicting future research opportunities. Wallin [17] defined systematic review as a method of document identification that can identify, evaluate, and comprehensively analyse basic research to answer specific topics. The systematic review method provides a transparent and replicable selection process that can improve the validity and reliability of research results.

First, both the Scopus and Web of Science databases were used to perform a systematic search of the relevant literature. This is because they not only cover a broad range of scientific publications but also have a high indexing speed. The search continued until the end of April 2021. The formula for the search string was as follows: 'blockchain' OR 'smart contract' OR 'distributed ledger' AND 'architecture' OR 'engineering' OR 'construction' OR 'design' OR 'building'. A total of 1453 articles were initially identified in the preliminary search. Journal or conference articles written in English were retained. Duplicate literature from the two databases was then eliminated. Thus, 1012 articles were finally identified and retrieved for further analysis. 
Next, we implemented a two-stage selection strategy based on the following criteria: (a) blockchain is the main research theme in the article (because some articles mentioned the concept of blockchain although it was not the focus of the study); and (b) the application field of blockchain is related to the AEC industry. For the first stage, we carefully checked the title, abstract, and keywords of each article. Next, we carefully reviewed the content of the selected articles to ensure that they were closely related to the RQs. A total of 137 articles were selected for the analysis. Finally, we downloaded and read the full text of these articles. Among them, 7 articles were incomplete, and 35 were inconsistent with the research topics. Additionally, 15 articles were obtained from other databases through snowball sampling. Finally, a total of 116 articles were retained. The process is illustrated in Figure 1.
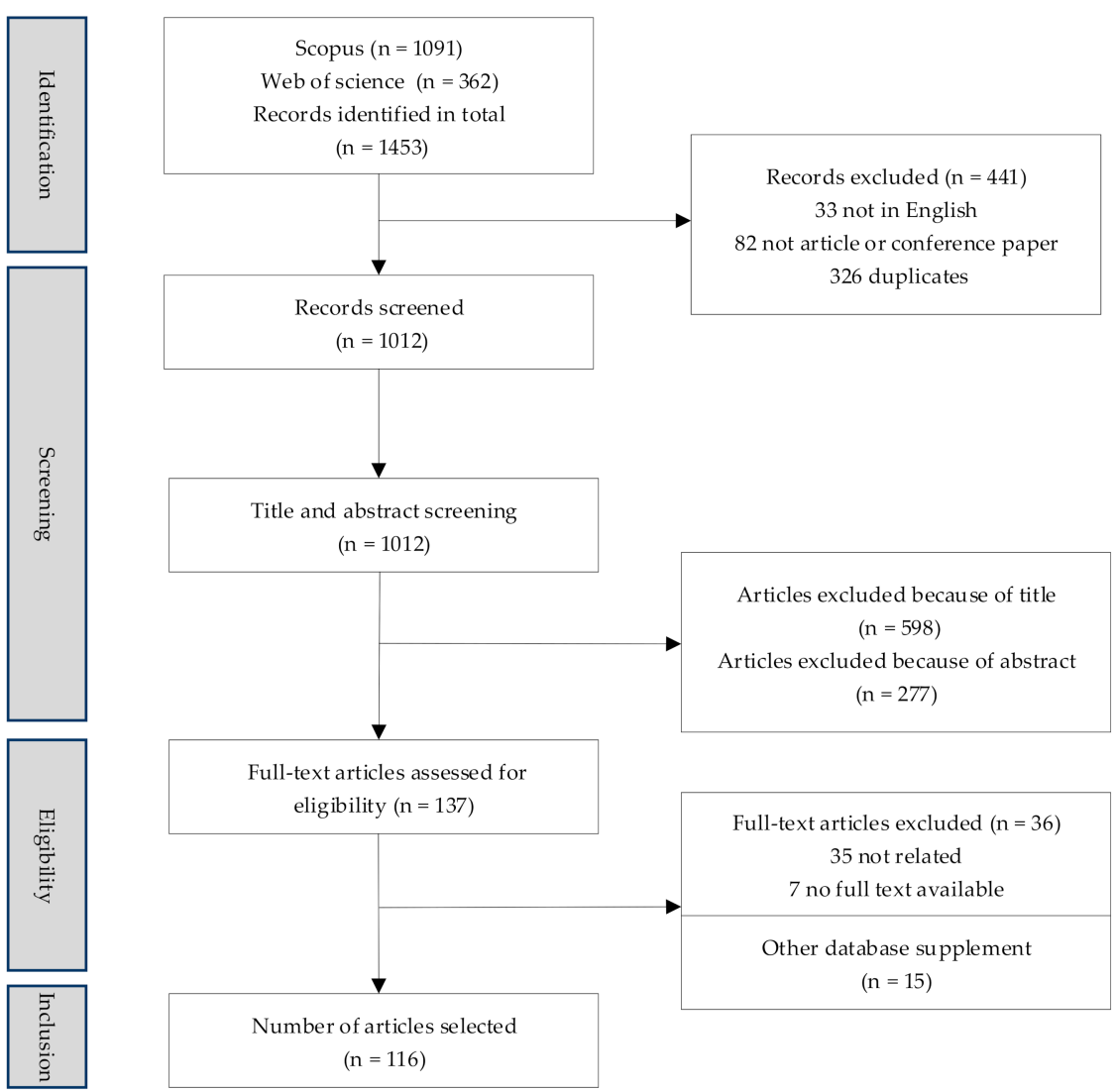

Figure 1. Overall flow of the review process and strategy.

\section{Results of Bibliometric Analysis}

To answer RQ1, a bibliometric analysis was conducted for constructing science maps regarding the publication years, journals, countries, institutions, authors, research methods, and author keywords.

\subsection{Chronological Publication Trend}

The publication trend of blockchain applications in the AEC industry is shown in Figure 2. The first related paper was published in 2015, indicating that blockchain research is relatively new. Between 2008 and 2020, the total number of publications increased significantly, reaching 45 in 2020. This reflects the popularity of this research topic. Additionally, the number of published conference papers was almost double the number of journal papers between 2017 and 2019. This gap narrowed from 2019 to 2020; in 2020, journal papers outnumbered conference papers for the first time. This may be because preliminary research results and general concepts were reported at the early stage. 


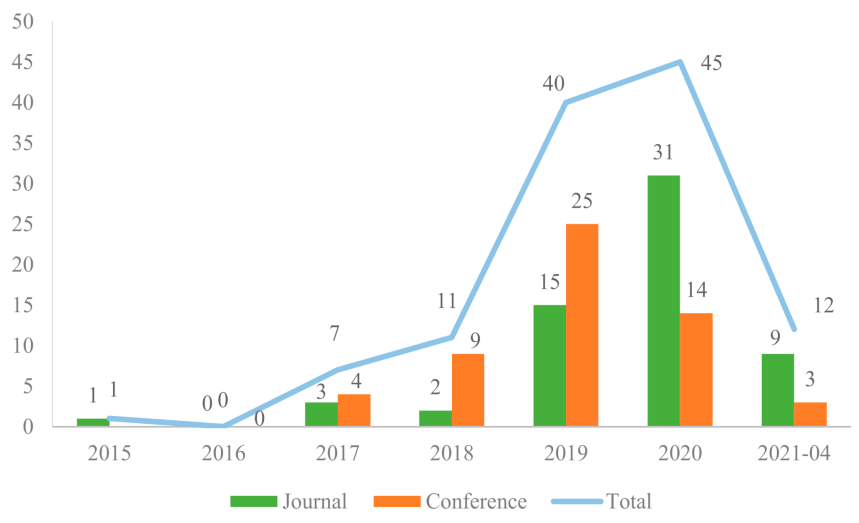

Figure 2. Paper distribution based on publication years.

\subsection{Journals}

A total of 36 journals were identified from the selected articles. Figure 3 presents the top eight journals with regard to the total number of publications. The largest number of publications (12 articles) came from Automation in Construction. The impact factor of this journal is 7.7, indicating its high impact. Frontiers of Engineering Management and Journal of Legal Affairs and Dispute Resolution in Engineering and Construction published five and four articles, respectively. Buildings had the fourth-most published articles, with a total of three articles. Therefore, these journals are crucial in the blockchain-based AEC industry, attracting scholars worldwide to submit their manuscripts.

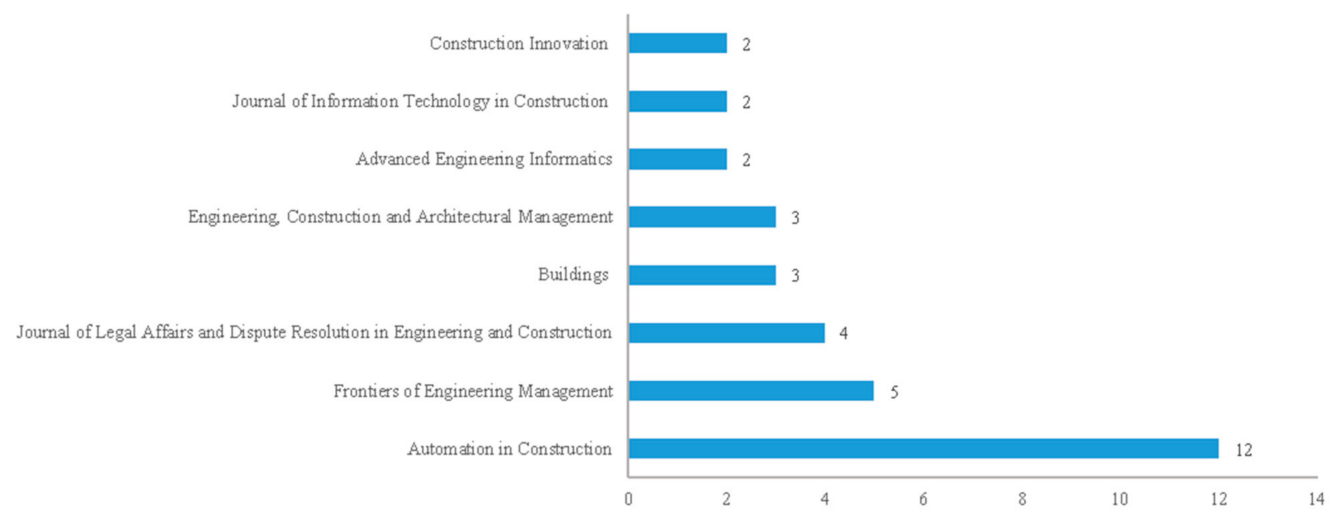

Figure 3. Top eight journals with regard to the number of articles published.

\subsection{Countries}

In Figure 4, the colours represent clusters and the three main clusters are illustrated. As shown, the collaboration network of countries forms a cluster of academic cooperation with Australia, the United Kingdom, and China as the core. Cluster 1 (red) includes three countries, cluster 2 (green) includes three countries, and cluster 3 (blue) includes two countries. Each node represents a country, and its size reflects the number of papers contributed by the authors in that country.

According to the node sizes shown in Figure 4, scholars from China were ranked first in terms of the number of publications ( 26 articles). This may be related to the Chinese government's regard for blockchain as a national strategy. Chinese scholars were followed by those from the United Kingdom and Australia, who contributed 23 and 19 articles, respectively. Thus, it can be considered that blockchain in the AEC industry has received significant attention in these countries. The United Kingdom ranked first among the countries in terms of article citations; articles published in the United Kingdom were cited 321 times. Developing countries, such as Slovenia, Lithuania, and Finland, published only one or two articles. However, the average number of citations for these countries was 
large. For example, only one article was published in Slovenia, but it was cited 94 times; thus, Slovenia ranked fifth for citations, following South Korea. The results indicated that developing countries are gradually asserting their influence in this area.

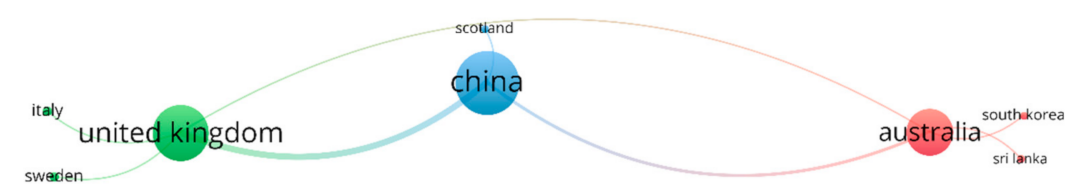

\section{\& VOSviewer}

Figure 4. Network of cooperation between countries.

Concerning research linkages, the United Kingdom has the largest number of links (eight), indicating that it has collaborations with other countries. Next, China and Australia have seven and five links, respectively. The links in Figure 4 represent the existing cooperation between countries, and their thicknesses indicate the strength of cooperation between the two countries. The China-United Kingdom links were the strongest (4). Weak United Kingdom-Australia and Australia-South Korea linkages existed. Table 1 presents the top 10 countries with regard to the total number of published papers.

Table 1. Top 10 countries with regard to the total number of published papers.

\begin{tabular}{lllll}
\hline No. & Countries & Documents & Citations & Average Citations \\
\hline 1 & China & 26 & 172 & 6.62 \\
2 & United Kingdom & 23 & 321 & 13.96 \\
3 & Australia & 19 & 220 & 11.58 \\
4 & United States & 12 & 89 & 7.42 \\
5 & Sweden & 5 & 21 & 4.20 \\
6 & Malaysia & 5 & 13 & 2.60 \\
7 & Italy & 4 & 13 & 3.25 \\
8 & India & 4 & 4 & 1.00 \\
9 & Russian & 2 & 18 & 9.00 \\
10 & Scotland & 2 & 2 & 1.00 \\
\hline
\end{tabular}

\subsection{Analysis of Collaborative Networks of Institutions and Authors}

A total of 110 institutions were identified from selected articles. The size of the node reflected the number of articles published by the institution [18]. As shown in Figure 5, Northumbria University had the largest node size, with 105 citations of the 6 published studies. Western Sydney University was ranked second, with 84 citations of 6 articles. The University of Florida was ranked third, with 63 citations of 5 articles. However, the distribution of the cooperation network of author institutions was relatively scattered. This is because blockchain research in the AEC industry is still in its infancy, and cooperation between institutions is not yet close. A feature of VOSviewer is that it groups the institutions into coloured clusters. Different clusters are represented by different colours. Cooperation exists between the institutions within the cluster. For example, as indicated by cluster 1 (red), six institutions (Central China Normal University; Curtin University; Hong Kong University of Science and Technology; Huazhong University of Science and Technology; Hubei Engineering Research Center for Virtual, Safe, and Automated Construction; and Kyung Hee University) have forged collaborative relationships with each other. 


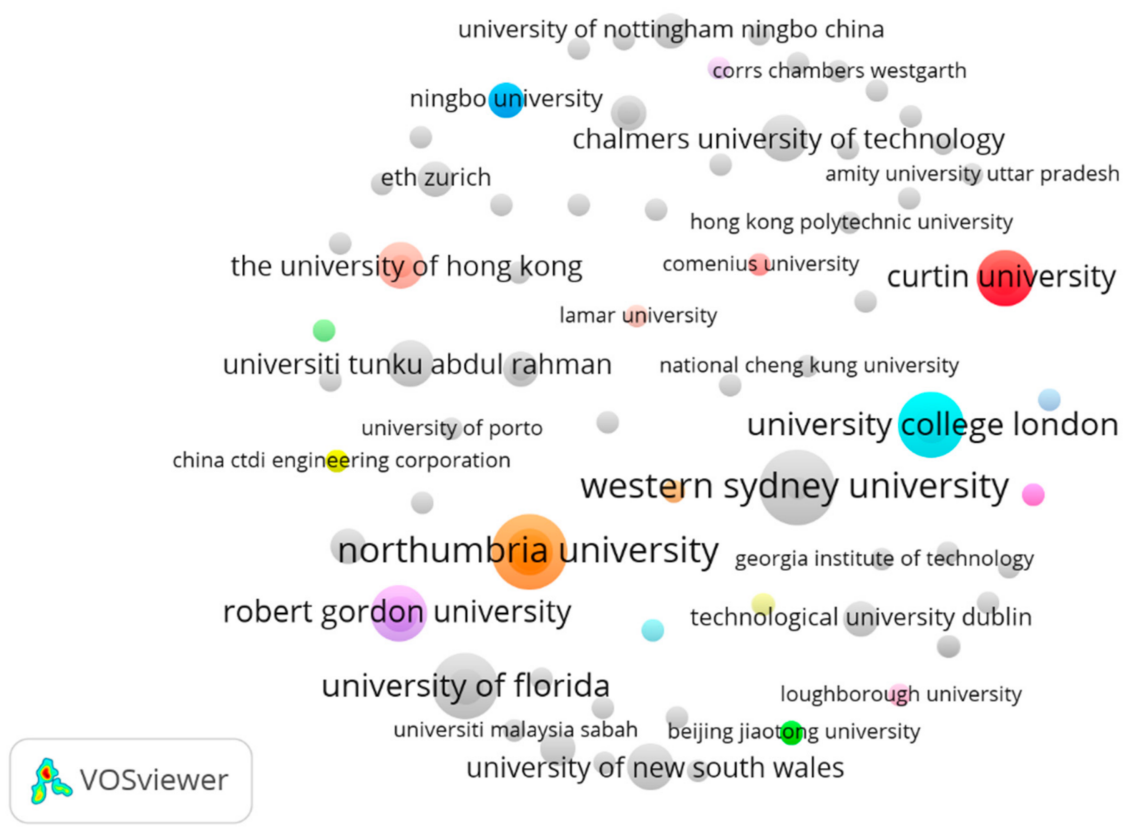

Figure 5. Network of cooperation between institutions.

A total of 278 researchers were identified from selected articles related to blockchain research in the AEC industry. The nodes were coloured according to the network links of the researchers. As shown in Figure 6, different clusters were represented by various colours, with each cluster being established around 1-3 core authors. The author cooperation network exhibited a decentralised layout. The largest author collaborative network cluster (red) was centred on Shou, WC., Cheng J.C.P., and Chen J., with a total of 13 authors. Among these authors, Li J. has published six articles, which were cited 105 times, making outstanding contributions to blockchain-related research in the AEC industry. Kassem M., Perera, S., Cheng J.C.P., and Das M. have published four articles each.

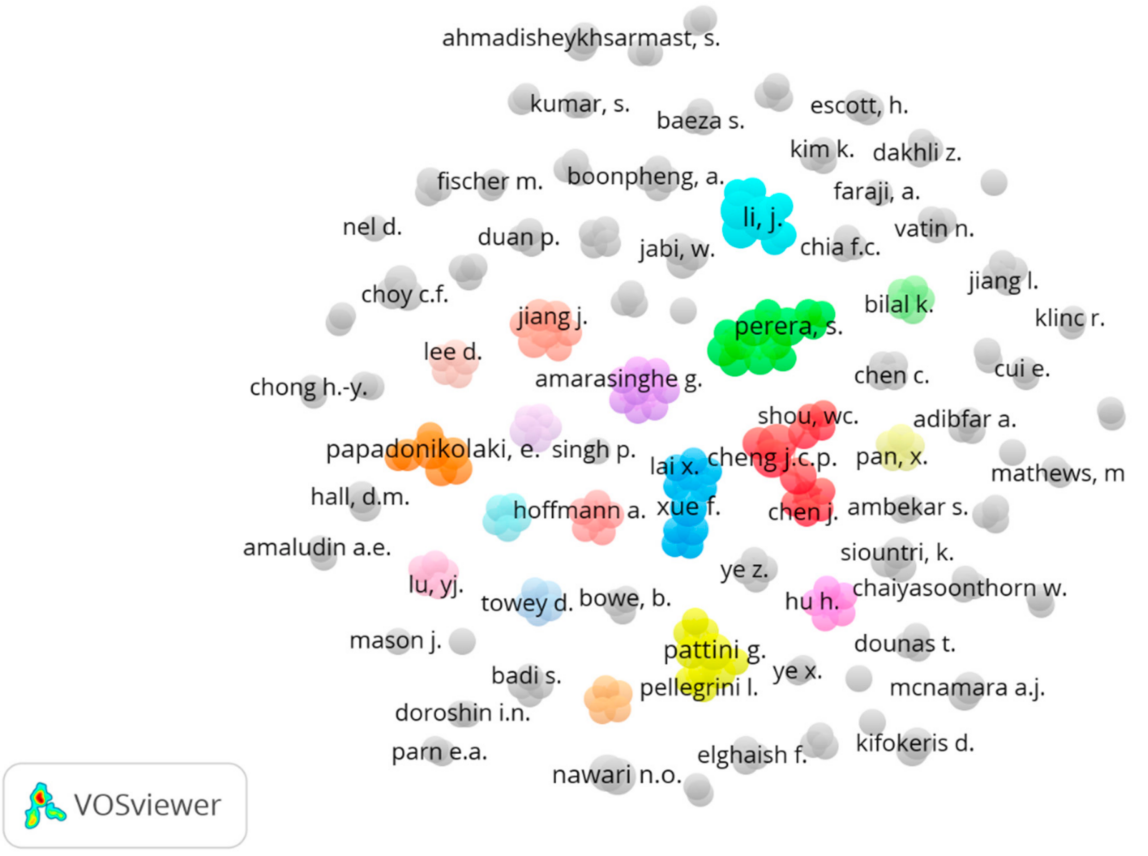

Figure 6. Author cooperation network. 


\subsection{Co-Occurrence Analysis of Keywords}

Author keywords were used to describe the co-occurrence network. Keywords with the same meaning or similar meanings were integrated, such as 'smart contracts' and 'smart contract'. The threshold value for keyword occurrence was set as two to improve the representativeness and comprehensiveness of the clustering results. As a result, 39 of 226 keywords reached the threshold value. Different colours represented different keyword clusters obtained using VOSviewer, and each cluster illustrated the corresponding association network. As shown in Figure 7, the co-occurring keywords were grouped into 10 clusters of different colours. For example, cluster 1 (red) refers to 'smart contract', and the main keywords were 'construction automation', 'construction contract', 'distributed ledger', 'information trust', 'procedure', and 'security of payment'. Cluster 2 (green) refers to 'BIM', and the main keywords were 'application', 'building information management', 'contract management', 'experience', 'supply chain management' (SCM), and 'trust'.

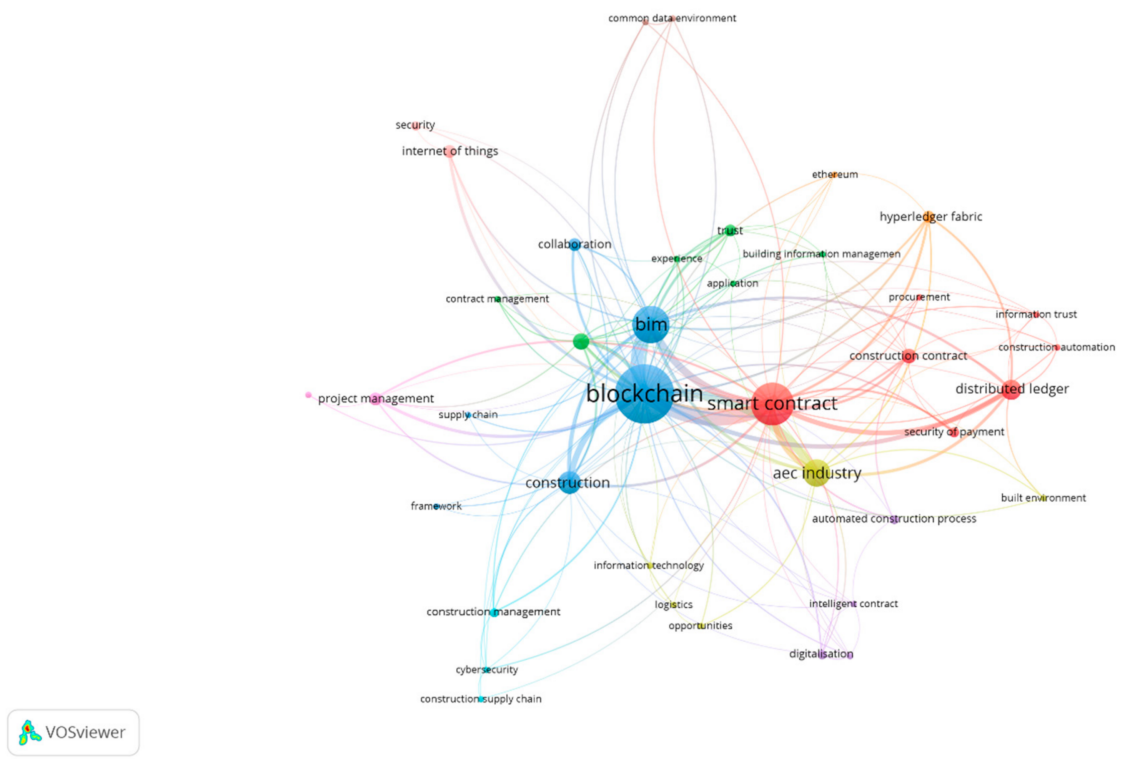

Figure 7. Keyword co-occurrence network.

In Figure 7, the node size indicates the occurrence frequency of each keyword. A larger node indicates that the keyword occurs more frequently in the literature. A thicker line between two keywords indicates a stronger association between their respective research areas [19]. As shown in Figure 7, 'BIM' and 'AEC industry' were the most frequently occurring keywords, excluding 'blockchain' and 'smart contracts'. A BIM is defined as a virtual three-dimensional building model that integrates a database of building elements [20]. Thus, the results indicate that the integration of BIM and blockchain has attracted considerable attention in the AEC industry. Moreover, SCM, construction contract management, construction automation, information management, and stakeholder management are research hotspots for blockchain in the AEC industry. However, few studies have addressed the challenges of blockchain applications in the AEC industry.

\subsection{Research Methodologies}

By reviewing selected articles, nine research methods were identified: general description, literature review, case study, questionnaire, expert interview, analytical hierarchy process (AHP), simulation modelling, interpretive structural modelling, and framework description. Conceptual analysis was used in $40 \%$ of the studies, which is consistent with the development of emerging research fields. This was followed by framework description $(23 \%)$ and literature review (13\%), as shown in Figure 8. 

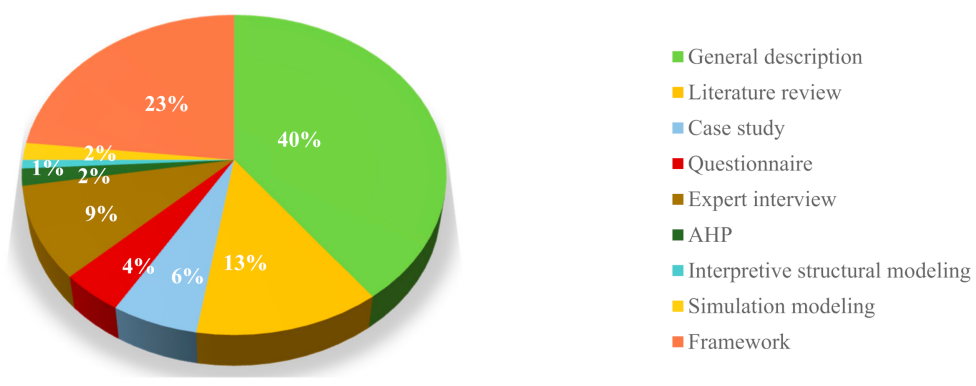

Figure 8. Classification of studies using different research methodologies.

\section{Results of Systematic Review}

In this section, we answer RQ2 and RQ3.

RQ2. What are the benefits of blockchain applications in the AEC industry?

By analysing and comparing the selected publications, the main benefits of blockchain in the AEC industry were summarised. Figure 9 illustrates the benefits of blockchain applications in five areas: SCM, contract management, information management, stakeholder management, and integration management. For detailed information about the selected articles, see Appendix A.

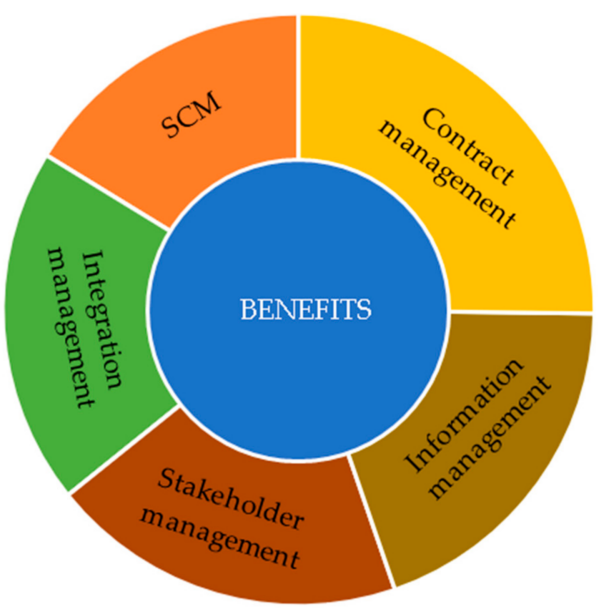

Figure 9. Benefits of blockchain applications in five areas.

\subsection{SCM}

There have been many studies on the construction supply chain (22 articles). SCM involves design documents, purchased equipment, materials, human resources, and engineering equipment. The construction industry has a complex supply chain, and blockchain can enhance the present SCM process through the use of public licenses [11]. The construction industry routinely relies on documents or centralised platforms to manage relevant information, from project procurement to final delivery. Information security is one of the main challenges faced by construction SCM, because of transparency and trust issues [21]. Blockchain can address these challenges by enhancing the transparency and traceability of the construction process. For example, Wang et al. [7] constructed a blockchain-based framework to improve supply chain traceability and information sharing during precast construction. Similarly, Zhang et al. [22] proposed an integrated framework based on blockchain that can effectively achieve decentralisation and openness. Additionally, the influence mechanism of blockchain on trust has received attention. Qian and Papadonikolaki [6] examined how blockchain affects trust in construction SCM according to industry experience. The results indicated that blockchain benefits trust relationships through system- and cognitive-based trust, reducing the demand for establishing trust. Sun and Wang [23] used an analytic hierarchy process to analyse the relationship between blockchain and trust. 
Through an empirical investigation, De La Peña and Papadonikolaki [24] identified nine intrinsic blockchain attributes that promote customer trust in contractors.

\subsection{Contract Management}

There were 25 articles on contract management. Most of them discussed the potential benefits of blockchain in construction contracts, and some focused on the general concepts. For example, Dakhli et al. [13] and Shou et al. [12] discussed the potential application of smart contracts in the construction industry and confirmed their advantages for improving time efficiency and cost savings. According to these studies, the benefits of smart contracts include the reduction of paperwork and the resolution of non-payment, late payment, and trust issues in construction contracts. Furthermore, the design of the smart-contract secure payment framework was investigated. Froese et al. (2007) emphasised that problems related to project payment are common in the construction industry. The application of smart contracts in the AEC industry can alleviate these problems. For example, Ahmadisheykhsarmast and Sonmez [25] designed a payment security system based on smart contracts and demonstrated its utility in making construction payments using actual engineering cases. A smart construction contract framework for automating construction payments was proposed by Luo et al. [26]. Ye and König [27] proposed an automatic billing framework that combines a BIM with smart contracts to simplify the payment and construction processes. Chong and Diamantopoulos [28] found that smart contracts are recognised as an advanced technology for solving construction payment security problems, and they developed a DFD framework that integrated blockchain and other advanced technologies to support the implementation of automated payment systems.

\subsection{Information Management}

There were 21 articles on information management. They mainly discussed the application of blockchain to construction documents, particularly for resolving transparency and trust issues. Owing to the complexity of construction projects, a large amount of data must be recorded and stored during project implementation. Additionally, such projects face various changes over time, requiring multiple revisions of construction information. Thus, there may be trust issues, information errors, and difficulties in regulation. Blockchain is a key solution that provides a reliable information-management infrastructure at all project stages. It improves the security and timeliness of data storage and recording during construction $[9,29,30]$ and facilitates efficient and traceable data changes [31,32]. Furthermore, construction projects involve many stakeholders. Therefore, information sharing and integration are critical to the success of such projects. However, poor collaboration is common in the AEC industry. Blockchain is useful for solving these problems. For example, to address the problem of automated information sharing in a prefabricated supply chain, Wang et al. [7] designed and evaluated a blockchain-based BIMF-PSC model. Jo et al. [33] proposed a distributed architecture and evaluated its effectiveness of the model for data security and transparent information sharing. Yang et al. [11] found that blockchain can record and track transaction information. Moreover, they reported that informationintegration benefits reduce the fragmentation and complexity of the industry and ensure transparent, traceable information sharing. Scholars have also studied the quality of information management in construction projects. For example, Sheng et al. [34] performed construction quality information management with blockchains and achieved a consistent, safe, and high-quality information management system. Zhong et al. [35] proposed a blockchain-based framework to realise a distributed, encrypted, secure database record and support automated compliance checks, promoting construction quality management.

\subsection{Stakeholder Management}

There was a total of 13 articles related to stakeholder management research. Most of them stated that blockchain can achieve its potential by enhancing collaboration among stakeholders. Goh et al. [36] and Shi et al. [37] proved that blockchain can improve the 
efficiency of stakeholder collaboration and enhance construction quality. Other researchers examined the needs and opinions of stakeholders regarding blockchain adoption in the AEC industry. For example, Nanayakkara et al. [38] investigated the views of stakeholders regarding blockchain applications in the Australian construction industry and identified 18 unique views. The most prominent factors were efficiency, trust, fairness, safety, transparency, accountability, compliance, and standardisation. Chaveesuk et al. [39] used an extended TAM model to analyse the determinants of the Thai construction industry's intention to adopt blockchain. Specifically, the perceived financial costs, convenience, trust, and readiness directly affected the behavioural intentions and had an indirect effect on perceived usefulness and ease of use. Although many studies have indicated that stakeholders have a positive attitude towards the adoption of blockchain, there are opposing opinions. For example, Mason and Escott [40] investigated stakeholder attitudes towards technology and concluded that the full realisation of automation is doubtful.

\subsection{Integration Management}

Many papers (up to 39) focused on the theme of integration. Table 2 presents the integration of blockchain with the Internet of Things (IoT), BIM, and other emerging technologies. Among them, the integration of blockchain with BIM has been most widely explored. For example, Xue and $\mathrm{Lu}$ [41] developed an innovative semantic difference transformation model that can capture continuous and synchronous changes, minimising information redundancy and supporting BIM and blockchain integration. Only one study focused on the integration of blockchain with Big Data to optimise the management of architectural employees. Integrating blockchain with BIM and IoT has attracted the attention of scholars in the AEC industry. This is because blockchain can solve many problems in the industry, e.g., enhancing trust in automatic payment, efficient procurement, transformation of the construction process, and design information management. Additionally, the integration of blockchain with multiple emerging technologies has attracted the interest of scholars. Lokshina et al. [42] investigated the application of integrated BIM, IoT and blockchain technologies in system design of a smart building. These technologies are complementary and can be combined to enhance information security management and improve the provision of IoT services. However, the integration of blockchain with artificial intelligence (AI) and machine learning (ML) is mostly at the conceptual stage. For example, Mathews et al. [43] introduced the integration of blockchain with AI and ML but did not conduct an in-depth study.

RQ3. What are the challenges of blockchain applications in the AEC industry?

Although blockchain offers many potential benefits to the AEC industry, several challenges must be addressed. The nine types of blockchain application challenges are presented in Figure 10. These were divided into technical (45 articles), organisational (29 articles), and environmental (27 articles) challenges. Details regarding the identified challenges are discussed below.

\subsection{Technology-Related Challenges}

A total of 45 articles dealt with challenges related to blockchain that hinder its application. The challenges described in the literature include those pertaining to throughput and latency, scalability limitations, technical interoperability issues, speed and data storage limitations for large amounts of data, and smart-contract coding and deployment. Hunhevicz and Hall [5] summarised the use cases of blockchain in the construction of distributed-ledger technologies (DLTs), arguing that throughput, data storage, and interoperability may be constraints related to the final DLT design. Sheng et al. [34] and Kiu et al. [73] reported that smart-contract coding and deployment in the construction industry are challenging because construction contracts involve complex clauses and many participants. Li et al. [4] presented a forward-looking framework based on smart contracts and determined that DLT scalability and interoperability between systems are the main technical barriers. Additionally, some studies revealed that privacy and security are inter- 
related technical issues. According to the reports of Tezel et al. [74] and Hamledari and Fischer [75], blockchains are vulnerable to cyberattacks, wherein attackers gain control of most of the blockchain network. Fragmentary research has been performed on other challenges associated with integration, such as system integration challenges. Hijazi et al. [76] analysed 69 peer-reviewed studies and found gaps in addressing, checking, and verifying the availability and limitations of BIM-blockchain integration.

Table 2. Integrating blockchain with other technologies.

\begin{tabular}{|c|c|c|c|c|c|c|c|}
\hline \multirow{2}{*}{ Reference } & \multicolumn{7}{|c|}{ Digital Technology } \\
\hline & BIM & IoT & AI & BDA & ML & RFID & Sensors \\
\hline Jennifer Li [31] & $\checkmark$ & $\checkmark$ & & & & & \\
\hline Dounas and Lombardi [44] & $\checkmark$ & & & & & & \\
\hline Li et al. [45] & $\checkmark$ & $\checkmark$ & & & & & \\
\hline Xue and Lu [41] & $\checkmark$ & & & & & & $\checkmark$ \\
\hline Shojaei et al. [46] & $\checkmark$ & $\checkmark$ & & & & $\checkmark$ & $\checkmark$ \\
\hline Wei and Cui [47] & & & & $\checkmark$ & & & \\
\hline Lokshina et al. [42] & $\checkmark$ & $\checkmark$ & & & & $\checkmark$ & $\checkmark$ \\
\hline Ilin et al. [48] & & & & & & $\checkmark$ & \\
\hline Zheng et al. [49] & $\checkmark$ & & & & & & \\
\hline Mason [50] & $\checkmark$ & & & & & & \\
\hline Mathews et al. [43] & $\checkmark$ & $\checkmark$ & $\checkmark$ & & $\checkmark$ & & \\
\hline Singh [51] & & $\checkmark$ & & & & & \\
\hline Chew [52] & $\checkmark$ & & & & & & \\
\hline Liu et al. [9] & $\checkmark$ & & & & & & \\
\hline Ye et al. [53] & $\checkmark$ & $\checkmark$ & & & & & \\
\hline Siountri et al. [54] & $\checkmark$ & $\checkmark$ & & & & & \\
\hline Pellegrini et al. [55] & $\checkmark$ & & & & & & \\
\hline Shinde et al. [56] & $\checkmark$ & & $\checkmark$ & & $\checkmark$ & & \\
\hline Shojaei [29] & $\checkmark$ & $\checkmark$ & & & & $\checkmark$ & \\
\hline Dounas et al. [57] & $\checkmark$ & & & & & & \\
\hline De La Peña and Papadonikolaki [24] & & $\checkmark$ & & & & & \\
\hline Jo et al. [33] & & $\checkmark$ & & & & & \\
\hline O'Reilly and Mathews [58] & $\checkmark$ & $\checkmark$ & & & & & $\checkmark$ \\
\hline Safa et al. [59] & $\checkmark$ & & & & & & \\
\hline Elghaish et al. [60] & $\checkmark$ & & & & & & \\
\hline Chong and Diamantopoulos [28] & $\checkmark$ & & & & & $\checkmark$ & $\checkmark$ \\
\hline Hill [61] & & $\checkmark$ & & & & & \\
\hline Amaludin and Bin Taharin [32] & $\checkmark$ & & & & & & \\
\hline Dounas et al. [62] & $\checkmark$ & & & & & & \\
\hline Cardeira [63] & $\checkmark$ & & & & & & \\
\hline Di Giuda et al. [64] & $\checkmark$ & & & & & & \\
\hline Li et al. [65] & $\checkmark$ & & $\checkmark$ & & & & \\
\hline Hargaden et al. [66] & $\checkmark$ & & & & & & \\
\hline Heiskanen [67] & & $\checkmark$ & & & & & \\
\hline Siountri et al. [68] & $\checkmark$ & $\checkmark$ & & & & & \\
\hline Dounas et al. [69] & $\checkmark$ & & & & & & \\
\hline Lee et al. [70] & $\checkmark$ & $\checkmark$ & & & & & \\
\hline Das et al. [71] & $\checkmark$ & & & & & & \\
\hline Parn and Edwards [72] & $\checkmark$ & & & & & & \\
\hline
\end{tabular}




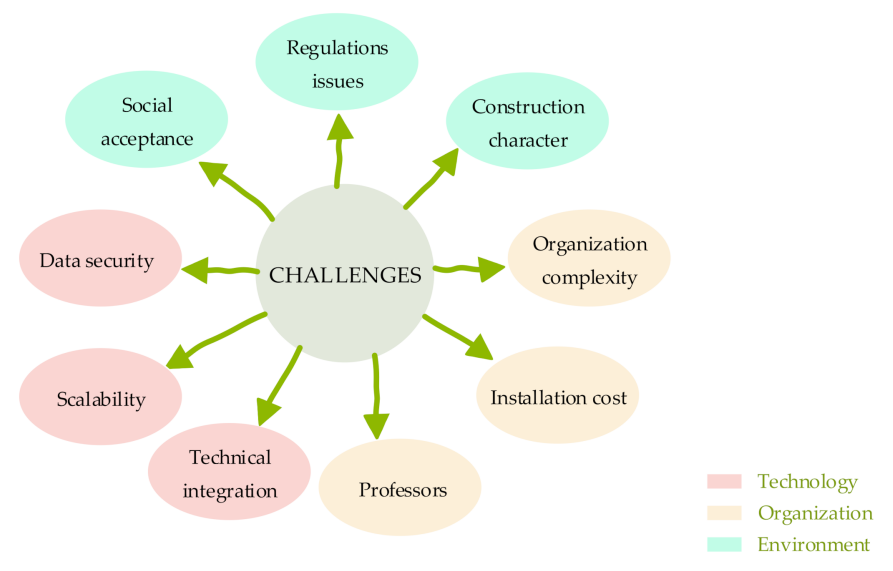

Figure 10. Challenges of blockchain applications in the AEC industry.

\subsection{Environmental Challenges}

The majority of the literature indicates that social acceptance is an important challenge faced by blockchain applications. Shojaei [29] and Dounas et al. [57] claimed that the blockchain application environment was not fully formed, owing to a lack of empirical cases. Li et al. [4] and Kifokeris and Koch [77] showed that the application of blockchain in the AEC industry remains in its infancy. These articles emphasised the absence of clear legislation in smart-contract management and enforcement. Moreover, research has been conducted on the characteristics of construction projects. For example, Wang et al. [7] investigated blockchain applications in the supply chain of prefabricated components. They found that it may be difficult to reuse existing blockchain networks, owing to the one-time nature of construction projects. Li et al. [45], McNamara and Sepasgozar [78], and Shojaei et al. [46] emphasised that smart contracts are suitable, owing to the high uncertainty and long-term nature of construction projects.

\subsection{Organisational Challenges}

A total of 29 articles dealt with the organisational challenges of blockchain technology. Most documents emphasised the absence of experts with the necessary technical skills and experience pertaining to blockchain, which limits the extent to which blockchain can be developed, deployed, and utilised. As blockchain application in the AEC industry remains in its infancy, most operators have not received adequate training and education [58]. Zhong et al. [35] reported that most construction-industry participants lack an understanding of the basic concepts and benefits of blockchain. Similar studies suggested that managers are hesitant to adopt blockchain and lack high-level planning $[39,79]$. Another factor to consider is the transition of the processes. Pattini et al. [80] reported that it is difficult to transition from physical documents (i.e., orders and invoices) to digital documents (i.e., smart contracts). Zhong et al. [35] claimed that there are few successful case references available, which limits blockchain's widespread adoption. A review of the literature reveals that the installation cost is high, which may reduce the willingness of decision makers to adopt blockchain. Additionally, as blockchain brings a way of thinking significantly different from that pertaining to traditional architecture, a reform of the culture and governance model may be a significant change for the AEC industry. Several studies have revealed the challenges faced by blockchain applications due to stakeholders' reluctance to share private information. Related challenges include organisational complexity and the imbalance caused by blockchain applications. The existence of many stakeholders may result in conflicting goals, with the potential for various intermediaries to disappear, which causes divergence and increases the complexity. For example, Kifokeris and Koch [81] reported that, in the social material construction logistics environment, where contractors dominate, blockchain application will disrupt the existing balance of power; contractors must give up a certain degree of control. 


\section{Discussion}

Blockchain applications in the AEC industry have attracted considerable attention. However, the summary and prospects of the RQ-related topics are still insufficient. To respond to the main $R Q$, we designed three RQs. In this section, the response is described. RQ1. What is the present status of blockchain applications?

The descriptive analysis included publication years, journals, institutions, countries, cooperation networks between authors, keyword co-occurrence networks, and research methodologies. An analysis of the number of annual publications revealed that, since 2016, the number of publications in the AEC industry has been increasing. A global analysis indicated that China was the main contributor to the topic, providing the largest number of publications. However, with regard to the paper citation rate, the United States far exceeds China, ranking first. This is because research in America started earlier than that in China. Li J., Kassem M., Perera S., Cheng J.C.P., and Das M. have made outstanding contributions to research related to blockchain applications in the AEC industry. Keyword analysis indicates the importance of contract management, stakeholder management, and SCM. Analysis of research methods revealed that general concepts are used most frequently, which are typically insufficient in empirical research and case studies.

RQ2. What are the benefits of blockchain applications in the AEC industry?

In-depth research of the identified themes revealed that blockchain can solve a series of problems in the AEC industry. The main benefits are divided into SCM, contract management, information management, stakeholder management, and integration management. Integration management-particularly the integration of BIM and blockchain-has received widespread attention. Regarding contract management, automated payment is the most promising area for blockchain to address problems in the AEC industry. With regard to information management, blockchain promotes information recording, storage, sharing, and integration owing to its traceability, disintermediation, and transparency. However, research on stakeholder management is insufficient.

RQ3. What are the challenges of blockchain applications in the AEC industry?

Despite the potential benefits, several challenges must be overcome. The selected publications mainly focused on the benefits; few studies have focused on the challenges. Our research findings confirmed the technology-organisation-environment (TOE) framework. Nine challenges were identified, which were divided into technological, organisational, and environmental challenges. The research results indicated that the complexity of the technology (i.e., privacy, security, and scalability) presents a challenge. Additionally, enhanced flexibility, clarity, and responsiveness to regulations and taxation may affect the application of blockchain in the AEC industry $[82,83]$. The decision to adopt blockchain is not only a technical decision but also a commercial one [84]. This is because it requires a series of conditions, such as the support of senior leaders and an innovative organisational culture.

\section{Future Research Opportunities of Blockchain in AEC Industry \\ 6.1. Future Research Opportunities Based on Benefits}

The benefits of blockchain applications in the AEC industry have broad future research opportunities. Future research opportunities related to the benefits are discussed in this section.

In previous studies on the benefits of blockchain applications in the AEC industry, researchers mainly used qualitative methods, such as a conceptual framework. However, to address the actual situation, the adoption and implementation of blockchain require the correct analysis and quantification of the effects of different variables, which can be accomplished by encouraging researchers and practitioners to conduct empirical and casebased research, e.g., investigating the key drivers of blockchain application in the AEC industry. Additionally, there may be complex relationships between the various benefits. However, researchers have not yet clarified the relationships between these advantages. 
Construction projects involve a complex network of stakeholders, such as contractors, owners, subcontractors, and governments [85]. There are various differences in the goals and needs of these stakeholders [86]. For example, contractors may prefer the advantages of safe payment, while owners pay more attention to the processes of transparency and information sharing to reduce contractors' opportunistic behaviour. Understanding the needs of different stakeholders is critical for project success [87]. The existing advantages are mostly considered from a holistic perspective, and the stakeholders in the AEC industry are not classified and compared. In the future, comparative research between stakeholders can be conducted to identify the key driving force for blockchain applications.

\subsection{Future Research Opportunities Based on Challenges}

The literature regarding the challenges of blockchain applications in the AEC industry lacks quantitative research. In the future, an integrated ISM-DEMATEL method should be considered for an in-depth investigation of the challenges of blockchain applications in the AEC industry.

Nevertheless, future research must be able to address technical issues related to blockchain applications, such as throughput, security, scalability, and interoperability. Such work is limited, and relevant quantitative research on these topics remains scarce. Thus, investigations must focus on addressing these challenges. Data privacy is a critical issue in information science, but the AEC industry has not paid sufficient attention to this issue. Owing to participants' concerns about data theft during the process of transferring data to external systems, data security and privacy issues affect the accuracy of the process. Additionally, a certain degree of data control is critical for blockchain applications in the AEC industry. This is because project participants may be unwilling to share all the relevant information with competitors. Potential solutions for hiding multi-party transaction information should be investigated in future research. Blockchain is a relatively young and rapidly developing technology, and its applications in the AEC industry remain limited. Additionally, most of the research focuses on the application of mature blockchain technology rather than method improvements. Compared with blockchain research in other industries, research on blockchain applications in the AEC industry is lagging, with considerable room for further development and exploration.

Most previous studies focused on the technical challenges; the organisational and environmental challenges have been insufficiently covered. From a sustainable-development perspective, the relationship between project partners is vital. Organisations differ with regard to SCM analysis and transaction tracking. Additionally, before proceeding with implementation, it is necessary to understand the applicability of blockchain in a cultural context. For example, the barriers to blockchain application in the AEC industry in China may differ from those in other countries. These issues need to be explored further.

As research on blockchain applications in the AEC industry is still in its early stage, there is no standard to regulate the behaviour of practitioners. Researchers should perform scientific studies from theoretical and empirical perspectives to formulate standards and policies for the AEC industry. For example, by examining the role of blockchain in the AEC industry, we were able to develop corresponding standards.

\section{Conclusions}

A mixed-method review of existing research related to blockchain applications in the AEC industry was conducted to understand its current status, benefits, challenges, and future research opportunities. The results indicated that research on the application of blockchain is still relatively new. The main contributions and limitations of the study are summarised in this section. Additionally, according to the inductive method of data analysis, future research opportunities are suggested.

Our first contribution was the construction of science maps of the understudied 'blockchain and AEC industry' area, which include the top contributors, institutions, publication journals, and author keywords. These structured insights will assist researchers 
in understanding the present status of the research and lay a foundation for future research in the field.

Second, we presented a conceptual framework (Figure 9) that summarises and classifies the benefits of blockchain applications in five areas. This framework makes a novel theoretical contribution to help blockchain adoption by enhancing awareness of the potential advantages of blockchain for organisations.

Third, we provided up-to-date information related to the challenges of blockchain applications in the AEC industry by presenting a TOE framework. The challenges presented in Figure 10 offer opportunities for researchers and practitioners to eliminate technological (e.g., solve data security issues), organisational (e.g., provide relevant training to staff), and environmental (e.g., formulate relevant laws and regulations) barriers to blockchain adoption.

Fourth, we proposed future research opportunities for the application of blockchain in the AEC industry. These easily accessible reference points help researchers and practitioners to rethink and expand on current work. This methodological contribution of the present study lies in providing accurate quantitative information, specific characteristics, and functional limitations of blockchain applications in the AEC industry.

Despite these contributions, this study has limitations. First, when the benefits and challenges of blockchain applications in the AEC industry were discussed, some scattered research was not explored in detail. These studies are interesting and should be considered in future research. Second, with the increasing number of publications and depth of blockchain applications in the AEC industry, research results may be dynamic. Therefore, a similar review should be conducted in the next few years. Third, the search query was not comprehensive enough to capture all the literature related to blockchain. Therefore, Delphi studies that overcome these limitations should be conducted in the future. Finally, the Boolean query that was formulated for the search should be extended by including the keyword derivatives to more accurately reflect the topic.

Author Contributions: Conceptualisation, M.C. (Mengyuan Cheng) and G.L.; methodology, G.L. and Y.X.; writing - original draft preparation, M.C. (Mengyuan Cheng); writing-review and editing, M.C. (Ming Chi). All authors have read and agreed to the published version of the manuscript.

Funding: This research received no external funding.

Institutional Review Board Statement: Not applicable.

Informed Consent Statement: Not applicable.

Data Availability Statement: Not applicable.

Conflicts of Interest: The authors declare no conflict of interest.

\section{Appendix A}

Table A1. The selected articles and their characteristics.

\begin{tabular}{|c|c|c|c|c|c|c|}
\hline \multirow{2}{*}{ No } & \multirow{2}{*}{ Authors } & \multirow{2}{*}{ Year } & \multirow{2}{*}{$\begin{array}{l}\text { Publication } \\
\text { Type }\end{array}$} & \multirow{2}{*}{ Methods } & \multicolumn{2}{|l|}{ Findings } \\
\hline & & & & & Benefits & Threats \\
\hline 1 & $\begin{array}{l}\text { Jennifer } \mathrm{Li} \\
\text { [31] }\end{array}$ & 2020 & Conference & $\begin{array}{l}\text { Framework } \\
\text { description }\end{array}$ & $\begin{array}{l}\text { Increase traceability of a } \\
\text { digital record }\end{array}$ & $\begin{array}{l}\text { Scalability issues, } \\
\text { interoperability issues, initial } \\
\text { cost, digitalisation }\end{array}$ \\
\hline 2 & $\begin{array}{l}\text { Dounas and } \\
\text { Lombardi [44] }\end{array}$ & 2018 & Conference & $\begin{array}{l}\text { Framework } \\
\text { description }\end{array}$ & CAD + blockchain & Technology problem \\
\hline
\end{tabular}


Table A1. Cont.

\begin{tabular}{|c|c|c|c|c|c|c|}
\hline \multirow{2}{*}{ No } & \multirow{2}{*}{ Authors } & \multirow{2}{*}{ Year } & \multirow{2}{*}{$\begin{array}{l}\text { Publication } \\
\text { Type }\end{array}$} & \multirow{2}{*}{ Methods } & \multicolumn{2}{|l|}{ Findings } \\
\hline & & & & & Benefits & Threats \\
\hline 3 & $\begin{array}{l}\text { Kifokeris and } \\
\text { Koch [81] }\end{array}$ & 2020 & Journal & $\begin{array}{l}\text { Simulation } \\
\text { modelling }\end{array}$ & $\begin{array}{l}\text { Complement well-established } \\
\text { technologies, shared ledger } \\
\text { structure, reduction of } \\
\text { accounting rework }\end{array}$ & $\begin{array}{l}\text { Data unavailability, lack of } \\
\text { wide awareness, power } \\
\text { balances, security issues, } \\
\text { potential implementational } \\
\text { constraints }\end{array}$ \\
\hline 4 & $\begin{array}{l}\text { Xiong et al. } \\
{[88]}\end{array}$ & 2019 & Journal & $\begin{array}{l}\text { Framework } \\
\text { description }\end{array}$ & Construction supply chain & Extra weaknesses in security \\
\hline 5 & Li et al. [45] & 2019 & Conference & $\begin{array}{l}\text { Framework } \\
\text { description }\end{array}$ & $\begin{array}{l}\text { Speed up the process of } \\
\text { payment authorisation, trust, } \\
\text { cooperation }\end{array}$ & $\begin{array}{l}\text { Technical integration, } \\
\text { legislation, limited skills, the } \\
\text { complexity of the contract } \\
\text { network, security issues }\end{array}$ \\
\hline 6 & Das et al. [89] & 2021 & Journal & $\begin{array}{l}\text { Framework } \\
\text { description }\end{array}$ & $\begin{array}{l}\text { Facilitate document approval } \\
\text { workflows, data } \\
\text { confidentiality and integrity, } \\
\text { validate the authenticity of } \\
\text { document search results }\end{array}$ & \\
\hline 7 & Kim et al. [90] & 2020 & Journal & Questionnaire & $\begin{array}{l}\text { Address the security issues, } \\
\text { achieve a faster approval } \\
\text { process }\end{array}$ & $\begin{array}{l}\text { Lack of real case, processing } \\
\text { time consuming, data security } \\
\text { issues }\end{array}$ \\
\hline 8 & $\begin{array}{l}\text { Owusu et al. } \\
\text { [91] }\end{array}$ & 2020 & Conference & $\begin{array}{l}\text { Literature } \\
\text { review }\end{array}$ & $\begin{array}{l}\text { Contract management, } \\
\text { enhanced communication, } \\
\text { ensure transparency, secured } \\
\text { copyrighted, automated } \\
\text { contracting. }\end{array}$ & $\begin{array}{l}\text { Cyber threats, complex } \\
\text { structure }\end{array}$ \\
\hline 9 & $\begin{array}{l}\text { Fitriawijaya } \\
\text { et al. [92] }\end{array}$ & 2019 & Conference & $\begin{array}{l}\text { Simulation } \\
\text { modelling }\end{array}$ & Construction supply chain & \\
\hline 10 & Li et al. [93] & 2021 & Journal & $\begin{array}{l}\text { Framework } \\
\text { description }\end{array}$ & IoT + blockchain & $\begin{array}{l}\text { Capacity issue, QR codes, } \\
\text { skilled personnel }\end{array}$ \\
\hline 11 & $\begin{array}{l}\text { Xue and } \mathrm{Lu} \\
\text { [41] }\end{array}$ & 2020 & Journal & $\begin{array}{l}\text { Framework } \\
\text { description }\end{array}$ & BIM + blockchain & \\
\hline 12 & $\begin{array}{l}\text { Ahmadisheykhs } \\
\text { and Sonmez } \\
{[25]}\end{array}$ & $\begin{array}{l}\text { armast } \\
2020\end{array}$ & Journal & $\begin{array}{l}\text { Framework } \\
\text { description }\end{array}$ & Security of payment & Security threats \\
\hline 13 & Danielle [94] & 2020 & Journal & $\begin{array}{l}\text { General } \\
\text { description }\end{array}$ & $\begin{array}{l}\text { Contract management, } \\
\text { information management }\end{array}$ & \\
\hline 14 & $\begin{array}{l}\text { Shojaei et al. } \\
\text { [46] }\end{array}$ & 2020 & Conference & $\begin{array}{l}\text { Framework } \\
\text { description }\end{array}$ & BIM + blockchain & Scalability, complex project \\
\hline 15 & $\begin{array}{l}\text { Lokshina et al. } \\
\text { [42] }\end{array}$ & 2019 & Journal & $\begin{array}{l}\text { Framework } \\
\text { description }\end{array}$ & BIM + blockchain + IoT & \\
\hline 16 & Ilin et al. [48] & 2018 & Conference & $\begin{array}{l}\text { General } \\
\text { description }\end{array}$ & RFID + blockchain & \\
\hline 17 & $\begin{array}{l}\text { Wei and Cui } \\
\text { [47] }\end{array}$ & 2020 & Conference & $\begin{array}{l}\text { General } \\
\text { description }\end{array}$ & $\begin{array}{l}\text { Construction document } \\
\text { management }\end{array}$ & \\
\hline 18 & $\begin{array}{l}\text { Zheng et al. } \\
\text { [49] }\end{array}$ & 2019 & Journal & $\begin{array}{l}\text { General } \\
\text { description }\end{array}$ & BIM + blockchain & $\begin{array}{l}\text { Security, high power } \\
\text { consumption, time-consuming } \\
\text { verification, and transaction }\end{array}$ \\
\hline 19 & Mason [50] & 2019 & Journal & $\begin{array}{l}\text { General } \\
\text { description }\end{array}$ & BIM + blockchain & \\
\hline
\end{tabular}


Table A1. Cont.

\begin{tabular}{|c|c|c|c|c|c|c|}
\hline \multirow{2}{*}{ No } & \multirow{2}{*}{ Authors } & \multirow{2}{*}{ Year } & \multirow{2}{*}{$\begin{array}{l}\text { Publication } \\
\text { Type }\end{array}$} & \multirow{2}{*}{ Methods } & \multicolumn{2}{|l|}{ Findings } \\
\hline & & & & & Benefits & Threats \\
\hline 20 & $\begin{array}{l}\text { Mathews et al. } \\
\text { [43] }\end{array}$ & 2017 & Conference & $\begin{array}{l}\text { General } \\
\text { description }\end{array}$ & BIM + blockchain & \\
\hline 21 & $\begin{array}{l}\text { McNamara } \\
\text { and } \\
\text { Sepasgozar } \\
{[78]}\end{array}$ & 2018 & Conference & $\begin{array}{l}\text { Literature } \\
\text { review }\end{array}$ & $\begin{array}{l}\text { Optimising payments and } \\
\text { reducing delay }\end{array}$ & $\begin{array}{l}\text { Data security, industry } \\
\text { confidence, front-end work, } \\
\text { cultural shift }\end{array}$ \\
\hline 22 & $\begin{array}{l}\text { Hijazi et al. } \\
{[76]}\end{array}$ & 2019 & Conference & $\begin{array}{l}\text { Literature } \\
\text { review }\end{array}$ & Construction supply chain & $\begin{array}{l}\text { Integration issues, data } \\
\text { privacy, cost, change } \\
\text { management, supervision, } \\
\text { lack of practical applications }\end{array}$ \\
\hline 23 & $\begin{array}{l}\text { Raslan et al. } \\
\text { [95] }\end{array}$ & 2020 & Conference & $\begin{array}{l}\text { Literature } \\
\text { review }\end{array}$ & Information management & Experts, cost \\
\hline 24 & $\begin{array}{l}\text { Perera et al. } \\
\text { [15] }\end{array}$ & 2020 & Journal & $\begin{array}{l}\text { Literature } \\
\text { review }\end{array}$ & $\begin{array}{l}\text { Security, anonymity, } \\
\text { decentralisation, anti-fraud, } \\
\text { immateriality, and financial } \\
\text { incentives }\end{array}$ & $\begin{array}{l}\text { Data privacy, data storage, } \\
\text { scalability limitations, demand } \\
\text { for high computing power }\end{array}$ \\
\hline 25 & $\begin{array}{l}\text { Nawari and } \\
\text { Ravindran } \\
\text { [96] }\end{array}$ & 2019 & Journal & $\begin{array}{l}\text { Literature } \\
\text { review }\end{array}$ & $\mathrm{BCT}+\mathrm{BIM}+$ blockchain & \\
\hline 26 & $\begin{array}{l}\text { Nawari and } \\
\text { Ravindran } \\
\text { [97] }\end{array}$ & 2019 & Journal & $\begin{array}{l}\text { Literature } \\
\text { review }\end{array}$ & BIM + blockchain & \\
\hline 27 & $\begin{array}{l}\text { Pattini et al. } \\
\text { [80] }\end{array}$ & 2020 & Journal & $\begin{array}{l}\text { General } \\
\text { description }\end{array}$ & Information management & $\begin{array}{l}\text { Training, process transition, } \\
\text { uniform rules }\end{array}$ \\
\hline 28 & $\begin{array}{l}\text { Shemov et al. } \\
{[98]}\end{array}$ & 2020 & Journal & Case study & $\begin{array}{l}\text { Verification of documents, } \\
\text { automated procurement and } \\
\text { payment, CSC traceability }\end{array}$ & $\begin{array}{l}\text { High cost, time lag, size and } \\
\text { bandwidth, business-related } \\
\text { and operational challenges, } \\
\text { vulnerability attacks }\end{array}$ \\
\hline 29 & Singh [51] & 2020 & Conference & $\begin{array}{l}\text { General } \\
\text { description }\end{array}$ & IoT + blockchain & $\begin{array}{l}\text { Regulatory ambiguity, trust, } \\
\text { cost, governance, inconsistent } \\
\text { standards }\end{array}$ \\
\hline 30 & $\begin{array}{l}\text { Rodrigo et al. } \\
\text { [99] }\end{array}$ & 2018 & Conference & $\begin{array}{l}\text { Literature } \\
\text { review }\end{array}$ & Construction supply chain & \\
\hline 31 & $\begin{array}{l}\text { Kifokeris and } \\
\text { Koch [100] }\end{array}$ & 2019 & Conference & $\begin{array}{l}\text { Expert } \\
\text { interview }\end{array}$ & Digital building logistics & $\begin{array}{l}\text { Cybersecurity, integration } \\
\text { issues, technical } \\
\text { interoperability issues, work } \\
\text { practices and organizational } \\
\text { changes }\end{array}$ \\
\hline 32 & $\begin{array}{l}\text { Hamma- } \\
\text { adama et al. } \\
\text { [101] }\end{array}$ & 2020 & Conference & $\begin{array}{l}\text { Literature } \\
\text { review }\end{array}$ & $\begin{array}{l}\text { Contract management, } \\
\text { stakeholder management }\end{array}$ & Awareness, knowledge \\
\hline 33 & $\begin{array}{l}\text { Kifokeris and } \\
\text { Koch [77] }\end{array}$ & 2019 & Conference & $\begin{array}{l}\text { General } \\
\text { description }\end{array}$ & Stakeholder management & Trust and safety issues, experts \\
\hline 34 & $\begin{array}{l}\text { Sivula et al. } \\
\text { [102] }\end{array}$ & 2018 & Conference & $\begin{array}{l}\text { General } \\
\text { description }\end{array}$ & Construction supply chain & $\begin{array}{l}\text { Integration challenges, experts, } \\
\text { security issues }\end{array}$ \\
\hline 35 & Li et al. [103] & 2019 & Conference & $\begin{array}{l}\text { General } \\
\text { description }\end{array}$ & Technology, social politics & $\begin{array}{l}\text { Technical architecture, social } \\
\text { impact }\end{array}$ \\
\hline
\end{tabular}


Table A1. Cont.

\begin{tabular}{|c|c|c|c|c|c|c|}
\hline \multirow{2}{*}{ No } & \multirow{2}{*}{ Authors } & \multirow{2}{*}{ Year } & \multirow{2}{*}{$\begin{array}{l}\text { Publication } \\
\text { Type }\end{array}$} & \multirow{2}{*}{ Methods } & \multicolumn{2}{|l|}{ Findings } \\
\hline & & & & & Benefits & Threats \\
\hline 36 & $\begin{array}{l}\text { Kassem et al. } \\
\text { [104] }\end{array}$ & 2018 & Conference & $\begin{array}{l}\text { Framework } \\
\text { description }\end{array}$ & $\begin{array}{l}\text { Improve financing channels, } \\
\text { automate construction } \\
\text { activities, simplify verification } \\
\text { processes, resolve ownership } \\
\text { and rights verification, proof } \\
\text { of origin, and construction } \\
\text { payments }\end{array}$ & $\begin{array}{l}\text { Adequate bandwidth and } \\
\text { capacity, legal issues; lack of } \\
\text { technical staff, social } \\
\text { awareness }\end{array}$ \\
\hline 37 & Li et al. [4] & 2019 & Journal & $\begin{array}{l}\text { Literature } \\
\text { review }\end{array}$ & $\begin{array}{l}\text { Enhance cooperation, digital } \\
\text { twins, disintermediation, } \\
\text { efficiency, low transaction } \\
\text { costs, ownership and right } \\
\text { certification, provenance, } \\
\text { reduction of human error, } \\
\text { smart contracts, social benefits, } \\
\text { traceability, workstream } \\
\text { improvement }\end{array}$ & $\begin{array}{l}\text { Data authentication, } \\
\text { broadband and connectivity, } \\
\text { smart-contract coding, energy } \\
\text { consumption, exchange rate } \\
\text { fluctuations, interoperability, } \\
\text { laws, malicious attacks, } \\
\text { preparation for adoption, } \\
\text { skills, resistance to change, } \\
\text { industry technology status }\end{array}$ \\
\hline 38 & Goh et al. [36] & 2019 & Journal & $\begin{array}{l}\text { General } \\
\text { description }\end{array}$ & Stakeholder management & $\begin{array}{l}\text { Security, social awareness, } \\
\text { technical defects }\end{array}$ \\
\hline 39 & $\begin{array}{l}\text { Nawari and } \\
\text { Ravindran } \\
{[105]}\end{array}$ & 2019 & Journal & $\begin{array}{l}\text { General } \\
\text { description }\end{array}$ & BIM + blockchain & $\begin{array}{l}\text { Privacy, security, centralised } \\
\text { management entities, attack } \\
\text { risk, cost, scalability }\end{array}$ \\
\hline 40 & $\begin{array}{l}\text { Nanayakkara } \\
\text { et al. [106] }\end{array}$ & 2019 & Conference & $\begin{array}{l}\text { Literature } \\
\text { review }\end{array}$ & $\mathrm{SCM}$ & \\
\hline 41 & $\begin{array}{l}\text { Wang et al. } \\
\text { [7] }\end{array}$ & 2020 & Journal & $\begin{array}{l}\text { Framework } \\
\text { description }\end{array}$ & $\begin{array}{l}\text { Improve the traceability of } \\
\text { prefabricated components }\end{array}$ & $\begin{array}{l}\text { Throughput and latency, lack } \\
\text { of awareness, initial cost, } \\
\text { difficulty in reuse }\end{array}$ \\
\hline 42 & $\begin{array}{l}\text { Hewavitharana } \\
\text { et al. [107] }\end{array}$ & 2019 & Conference & $\begin{array}{l}\text { General } \\
\text { description }\end{array}$ & Contract management & \\
\hline 43 & Chew [52] & 2019 & Journal & $\begin{array}{l}\text { General } \\
\text { description }\end{array}$ & $\begin{array}{l}\text { Payment, SCM, BIM, smart } \\
\text { contract, effective carbon } \\
\text { tracking }\end{array}$ & \\
\hline 44 & $\begin{array}{l}\text { Boonpheng } \\
\text { et al. [108] }\end{array}$ & 2020 & Journal & $\begin{array}{l}\text { General } \\
\text { description }\end{array}$ & Data management & \\
\hline 45 & Liu et al. [9] & 2019 & Journal & $\begin{array}{l}\text { Framework } \\
\text { description }\end{array}$ & BIM+ blockchain & \\
\hline 46 & Luo et al. [26] & 2019 & Conference & $\begin{array}{l}\text { Framework } \\
\text { description }\end{array}$ & $\begin{array}{l}\text { Construction payment } \\
\text { automation }\end{array}$ & \\
\hline 47 & $\begin{array}{l}\text { Chen et al. } \\
\text { [109] }\end{array}$ & 2020 & Conference & Case study & Information management & \\
\hline 48 & $\begin{array}{l}\text { Sheng et al. } \\
\text { [34] }\end{array}$ & 2020 & Journal & $\begin{array}{l}\text { Framework } \\
\text { description }\end{array}$ & Information management & $\begin{array}{l}\text { Cost, capacity, coding and } \\
\text { deployment of smart contracts, } \\
\text { industry conflicts }\end{array}$ \\
\hline 49 & Ye et al. [53] & 2018 & Conference & $\begin{array}{l}\text { General } \\
\text { description }\end{array}$ & BIM + IoT+ blockchain & \\
\hline 50 & $\begin{array}{l}\text { Adibfar et al. } \\
{[110]}\end{array}$ & 2020 & Journal & $\begin{array}{l}\text { Literature } \\
\text { review }\end{array}$ & BIM + blockchain & \\
\hline 51 & $\begin{array}{l}\text { McNamara } \\
\text { and } \\
\text { Sepasgozar } \\
\text { [111] }\end{array}$ & 2020 & Journal & $\begin{array}{l}\text { Literature } \\
\text { review }\end{array}$ & Automated payment & Social awareness \\
\hline
\end{tabular}


Table A1. Cont.

\begin{tabular}{|c|c|c|c|c|c|c|}
\hline \multirow{2}{*}{ No } & \multirow{2}{*}{ Authors } & \multirow{2}{*}{ Year } & \multirow{2}{*}{$\begin{array}{l}\text { Publication } \\
\text { Type }\end{array}$} & \multirow{2}{*}{ Methods } & \multicolumn{2}{|l|}{ Findings } \\
\hline & & & & & Benefits & Threats \\
\hline 52 & $\begin{array}{l}\text { Siountri et al. } \\
{[54]}\end{array}$ & 2020 & Journal & $\begin{array}{l}\text { Framework } \\
\text { description }\end{array}$ & BIM + IoT+ blockchain & \\
\hline 53 & $\begin{array}{l}\text { Pellegrini } \\
\text { et al. [55] }\end{array}$ & 2020 & Journal & Case study & BIM + blockchain & \\
\hline 54 & $\begin{array}{l}\text { Prakash and } \\
\text { Ambekar } \\
\text { [112] }\end{array}$ & 2020 & Journal & $\begin{array}{l}\text { Expert } \\
\text { interview }\end{array}$ & $\begin{array}{l}\text { Construction payment } \\
\text { automation, SCM, BIM }\end{array}$ & \\
\hline 55 & $\begin{array}{l}\text { Hunhevicz } \\
\text { and Hall [5] }\end{array}$ & 2020 & Journal & Case study & Construction automation & $\begin{array}{l}\text { Throughput, data storage, } \\
\text { interoperability, privacy, cost }\end{array}$ \\
\hline 56 & $\begin{array}{l}\text { Shinde et al. } \\
\text { [56] }\end{array}$ & 2020 & Conference & $\begin{array}{l}\text { General } \\
\text { description }\end{array}$ & Contract management & \\
\hline 57 & Shojaei [29] & 2019 & Journal & $\begin{array}{l}\text { General } \\
\text { description }\end{array}$ & $\begin{array}{l}\text { Contract management, SCM, } \\
\text { BIM, facility management, } \\
\text { sustainability }\end{array}$ & Lack of feasibility \\
\hline 58 & Kiu et al. [73] & 2020 & Journal & $\begin{array}{l}\text { Literature } \\
\text { review }\end{array}$ & $\begin{array}{l}\text { SCM, BIM, construction } \\
\text { management, document } \\
\text { management, real estate } \\
\text { management and fund } \\
\text { management }\end{array}$ & Lack of empirical work \\
\hline 59 & $\begin{array}{l}\text { Ye and König } \\
\text { [27] }\end{array}$ & 2020 & Conference & $\begin{array}{l}\text { Framework } \\
\text { description }\end{array}$ & BIM + blockchain & $\begin{array}{l}\text { Limited storage and slow } \\
\text { transactions }\end{array}$ \\
\hline 60 & $\begin{array}{l}\text { Dounas et al. } \\
\text { [57] }\end{array}$ & 2020 & Journal & $\begin{array}{l}\text { Framework } \\
\text { description }\end{array}$ & BIM + blockchain & Industry awareness \\
\hline 61 & $\begin{array}{l}\text { De La Peña } \\
\text { and Pa- } \\
\text { padonikolaki } \\
\text { [24] }\end{array}$ & 2019 & Conference & $\begin{array}{l}\text { Expert } \\
\text { interview }\end{array}$ & IoT + blockchain & Industry awareness \\
\hline 62 & $\begin{array}{l}\text { Zhong et al. } \\
\text { [35] }\end{array}$ & 2020 & Journal & $\begin{array}{l}\text { Framework } \\
\text { description }\end{array}$ & Information management & $\begin{array}{l}\text { Lack of cases, lack of } \\
\text { understanding, initial costs, } \\
\text { construction companies' } \\
\text { unwillingness to privatise, } \\
\text { technical issues, policy } \\
\text { environment }\end{array}$ \\
\hline 63 & $\begin{array}{l}\text { Graham and } \\
\text { Hailer [113] }\end{array}$ & 2019 & Conference & $\begin{array}{l}\text { General } \\
\text { description }\end{array}$ & Risk management, SCM & $\begin{array}{l}\text { Lack of standardization, full } \\
\text { participation, technical } \\
\text { limitations }\end{array}$ \\
\hline 64 & $\begin{array}{l}\text { O'Reilly and } \\
\text { Mathews [58] }\end{array}$ & 2019 & Conference & $\begin{array}{l}\text { Framework } \\
\text { description }\end{array}$ & BIM + blockchain & Cultural change, education \\
\hline 65 & Safa et al. [59] & 2019 & Journal & $\begin{array}{l}\text { General } \\
\text { description }\end{array}$ & Information management & \\
\hline 66 & $\begin{array}{l}\mathrm{Li} \text { and } \\
\text { Kassem [114] }\end{array}$ & 2019 & Conference & $\begin{array}{l}\text { Expert } \\
\text { interview }\end{array}$ & Contract management & $\begin{array}{l}\text { smart-contract coding, } \\
\text { technical capabilities, laws, } \\
\text { and regulations }\end{array}$ \\
\hline 67 & $\begin{array}{l}\text { Elghaish et al. } \\
\text { [60] }\end{array}$ & 2020 & Journal & Case study & $\begin{array}{l}\text { Construction payment } \\
\text { automation }\end{array}$ & Technical issues \\
\hline 68 & $\begin{array}{l}\text { Chong and } \\
\text { Diaman- } \\
\text { topoulos } \\
{[28]}\end{array}$ & 2020 & Journal & Questionnaire & Payment security & $\begin{array}{l}\text { Blockchain platform type } \\
\text { selection, algorithm } \\
\text { development }\end{array}$ \\
\hline
\end{tabular}


Table A1. Cont.

\begin{tabular}{|c|c|c|c|c|c|c|}
\hline \multirow{2}{*}{ No } & \multirow{2}{*}{ Authors } & \multirow{2}{*}{ Year } & \multirow{2}{*}{$\begin{array}{l}\text { Publication } \\
\text { Type }\end{array}$} & \multirow{2}{*}{ Methods } & \multicolumn{2}{|l|}{ Findings } \\
\hline & & & & & Benefits & Threats \\
\hline 69 & Mason [115] & 2017 & Journal & $\begin{array}{l}\text { General } \\
\text { description }\end{array}$ & BIM + blockchain & $\begin{array}{l}\text { Reliability and interoperability, } \\
\text { creating coding codes }\end{array}$ \\
\hline 70 & $\begin{array}{l}\text { McNamara } \\
\text { and } \\
\text { Sepasgozar } \\
{[116]}\end{array}$ & 2021 & Journal & $\begin{array}{l}\text { Framework } \\
\text { description }\end{array}$ & Contract management & $\begin{array}{l}\text { Lack of technical personnel, } \\
\text { lack of successful cases, } \\
\text { cultural barriers }\end{array}$ \\
\hline 71 & $\begin{array}{l}\text { Singh and } \\
\text { Ashuri [117] }\end{array}$ & 2019 & Conference & $\begin{array}{l}\text { General } \\
\text { description }\end{array}$ & Information management & $\begin{array}{l}\text { Speed under massive data, } \\
\text { limitation of data storage, } \\
\text { interoperability }\end{array}$ \\
\hline 72 & $\begin{array}{l}\text { Erri Pradeep } \\
\text { et al. [118] }\end{array}$ & 2019 & Conference & $\begin{array}{l}\text { General } \\
\text { description }\end{array}$ & BIM + blockchain & $\begin{array}{l}\text { Accuracy and scalability of } \\
\text { information }\end{array}$ \\
\hline 73 & $\begin{array}{l}\text { Hunhevicz } \\
\text { and Hall [119] }\end{array}$ & 2019 & Conference & $\begin{array}{l}\text { General } \\
\text { description }\end{array}$ & $\begin{array}{l}\text { Management process } \\
\text { automation, SCM }\end{array}$ & $\begin{array}{l}\text { Lack of awareness, skills, } \\
\text { resistance to change }\end{array}$ \\
\hline 74 & Hill [61] & 2020 & Conference & $\begin{array}{l}\text { General } \\
\text { description }\end{array}$ & IoT + blockchain & \\
\hline 75 & $\begin{array}{l}\text { Rodrigo et al. } \\
\text { [120] }\end{array}$ & 2020 & Journal & $\begin{array}{l}\text { Expert } \\
\text { interview }\end{array}$ & Construction Supply Chain & \\
\hline 76 & $\begin{array}{l}\text { Turk and } \\
\text { Klinc [30] }\end{array}$ & 2017 & Journal & $\begin{array}{l}\text { General } \\
\text { description }\end{array}$ & Information management & $\begin{array}{l}\text { The impact of availability is } \\
\text { uncertain }\end{array}$ \\
\hline 77 & $\begin{array}{l}\text { Tezel et al. } \\
{[121]}\end{array}$ & 2019 & Conference & $\begin{array}{l}\text { Expert } \\
\text { interview }\end{array}$ & Information management & $\begin{array}{l}\text { Security, scalability, human } \\
\text { resources, governance } \\
\text { mechanisms, laws, incentives }\end{array}$ \\
\hline 78 & $\begin{array}{l}\text { Tezel et al. } \\
{[74]}\end{array}$ & 2020 & Journal & $\begin{array}{l}\text { General } \\
\text { description }\end{array}$ & Construction supply chain & $\begin{array}{l}\text { Security, scalability, human } \\
\text { resources, governance } \\
\text { mechanisms, laws, incentives, } \\
\text { wait and see }\end{array}$ \\
\hline 79 & $\begin{array}{l}\text { Amaludin } \\
\text { and Bin } \\
\text { Taharin [32] }\end{array}$ & 2018 & Journal & $\begin{array}{l}\text { General } \\
\text { description }\end{array}$ & $\begin{array}{l}\text { Identity verification and } \\
\text { notarization, project } \\
\text { governance, BIM + blockchain }\end{array}$ & \\
\hline 80 & $\begin{array}{l}\text { Yang et al. } \\
{[11]}\end{array}$ & 2020 & Journal & Case study & $\begin{array}{l}\text { Business process management, } \\
\text { SCM, information } \\
\text { management }\end{array}$ & $\begin{array}{l}\text { Business change, identity, cost, } \\
\text { security, complexity of } \\
\text { adoption, scalability }\end{array}$ \\
\hline 81 & $\begin{array}{l}\text { Sun and } \\
\text { Wang [23] }\end{array}$ & 2020 & Conference & AHP & Construction supply chain & \\
\hline 82 & $\begin{array}{l}\text { Abrishami } \\
\text { and Elghaish } \\
{[122]}\end{array}$ & 2019 & Conference & $\begin{array}{l}\text { Framework } \\
\text { description }\end{array}$ & Stakeholder management & \\
\hline 83 & $\begin{array}{l}\text { Darabseh and } \\
\text { Martins [123] }\end{array}$ & 2020 & Journal & $\begin{array}{l}\text { Literature } \\
\text { review }\end{array}$ & $\begin{array}{l}\text { File ownership, smart } \\
\text { contracts, SCM, BIM, facility } \\
\text { management, sustainability }\end{array}$ & Culture \\
\hline 84 & $\begin{array}{l}\text { Hamledari } \\
\text { and Fischer } \\
{[75]}\end{array}$ & 2021 & Journal & $\begin{array}{l}\text { General } \\
\text { description }\end{array}$ & Automatic payment & Security \\
\hline 85 & Das et al. [8] & 2020 & Journal & $\begin{array}{l}\text { Framework } \\
\text { description }\end{array}$ & $\begin{array}{l}\text { Interim payment for } \\
\text { construction projects }\end{array}$ & \\
\hline 86 & $\begin{array}{l}\text { Qian and Pa- } \\
\text { padonikolaki } \\
{[6]}\end{array}$ & 2020 & Journal & $\begin{array}{l}\text { General } \\
\text { description }\end{array}$ & SCM & $\begin{array}{l}\text { Cost, social awareness, cost, } \\
\text { talent, transformation, }\end{array}$ \\
\hline
\end{tabular}


Table A1. Cont.

\begin{tabular}{|c|c|c|c|c|c|c|}
\hline \multirow{2}{*}{ No } & \multirow{2}{*}{ Authors } & \multirow{2}{*}{ Year } & \multirow{2}{*}{$\begin{array}{l}\text { Publication } \\
\text { Type }\end{array}$} & \multirow{2}{*}{ Methods } & \multicolumn{2}{|l|}{ Findings } \\
\hline & & & & & Benefits & Threats \\
\hline 87 & Faraji [124] & 2019 & Conference & Questionnaire & $\begin{array}{l}\text { Optimization of engineering } \\
\text { contracts }\end{array}$ & \\
\hline 88 & $\begin{array}{l}\text { Mason and } \\
\text { Escott [40] }\end{array}$ & 2018 & Conference & Questionnaire & Stakeholder management & $\begin{array}{l}\text { Automatically respond to } \\
\text { abnormal situations and } \\
\text { human attitudes }\end{array}$ \\
\hline 89 & Cardeira [63] & 2015 & Conference & $\begin{array}{l}\text { General } \\
\text { description }\end{array}$ & $\begin{array}{l}\text { Automate construction } \\
\text { payments }\end{array}$ & $\begin{array}{l}\text { Societal acceptance, } \\
\text { technology problem }\end{array}$ \\
\hline 90 & $\begin{array}{l}\text { Dounas et al. } \\
{[62]}\end{array}$ & 2020 & Conference & $\begin{array}{l}\text { General } \\
\text { description }\end{array}$ & BIM + blockchain & \\
\hline 91 & $\begin{array}{l}\text { Ahmadisheykhs } \\
\text { and Sonmez } \\
{[125]}\end{array}$ & $\begin{array}{l}\text { armast } \\
2018\end{array}$ & Conference & $\begin{array}{l}\text { General } \\
\text { description }\end{array}$ & Automatic payment & $\begin{array}{l}\text { Lack of training, price } \\
\text { fluctuations, industry } \\
\text { acceptance, legal }\end{array}$ \\
\hline 92 & $\begin{array}{l}\text { Nanayakkara } \\
\text { et al. [38] }\end{array}$ & 2019 & Conference & $\begin{array}{l}\text { Expert } \\
\text { interview }\end{array}$ & Stakeholder management & $\begin{array}{l}\text { Changes in technology, people, } \\
\text { organization, and construction } \\
\text { environment }\end{array}$ \\
\hline 93 & $\begin{array}{l}\text { Badi et al. } \\
\text { [126] }\end{array}$ & 2021 & Journal & Questionnaire & Stakeholder management & Observability, legal \\
\hline 94 & $\begin{array}{l}\text { Di Giuda et al. } \\
\text { [64] }\end{array}$ & 2020 & Journal & $\begin{array}{l}\text { General } \\
\text { description }\end{array}$ & BIM + blockchain & \\
\hline 95 & $\begin{array}{l}\text { Sharma and } \\
\text { Kumar [79] }\end{array}$ & 2020 & Journal & $\begin{array}{l}\text { Interpretive } \\
\text { structural } \\
\text { modelling }\end{array}$ & SCM & $\begin{array}{l}\text { Governance, supervision, } \\
\text { skills }\end{array}$ \\
\hline 96 & $\begin{array}{l}\text { Dakhli et al. } \\
\text { [13] }\end{array}$ & 2019 & Journal & $\begin{array}{l}\text { General } \\
\text { description }\end{array}$ & $\begin{array}{l}\text { Potential cost savings, } \\
\text { construction process }\end{array}$ & $\begin{array}{l}\text { Security, slow speed, } \\
\text { regulations, immature } \\
\text { technology, privacy, audit } \\
\text { requirements, data quality }\end{array}$ \\
\hline 97 & San et al. [14] & 2019 & Conference & $\begin{array}{l}\text { Literature } \\
\text { review }\end{array}$ & $\begin{array}{l}\text { Contract management, BIM, } \\
\text { EDM, property management, } \\
\text { SCM, fund management }\end{array}$ & $\begin{array}{l}\text { Regulatory approach, slow } \\
\text { adoption of construction } \\
\text { technology }\end{array}$ \\
\hline 98 & $\begin{array}{l}\text { Hargaden } \\
\text { et al. [66] }\end{array}$ & 2019 & Conference & $\begin{array}{l}\text { General } \\
\text { description }\end{array}$ & $\begin{array}{l}\text { Information management, } \\
\text { contract management }\end{array}$ & \\
\hline 99 & Belle [127] & 2017 & Conference & $\begin{array}{l}\text { Theoretical } \\
\text { concept }\end{array}$ & $\begin{array}{l}\text { Protection of intellectual } \\
\text { property rights, building } \\
\text { reputation, contract } \\
\text { management }\end{array}$ & $\begin{array}{l}\text { The capabilities of the industry } \\
\text { to cooperate and organise } \\
\text { work processes }\end{array}$ \\
\hline 100 & Cardeira [128] & 2017 & Conference & $\begin{array}{l}\text { General } \\
\text { description }\end{array}$ & BIM + blockchain & \\
\hline 101 & Li et al. [65] & 2021 & Journal & $\begin{array}{l}\text { General } \\
\text { description }\end{array}$ & $\mathrm{AI}+\mathrm{BIM}+$ blockchain & \\
\hline 102 & $\begin{array}{l}\text { Qian and Pa- } \\
\text { padonikolaki } \\
\text { [129] }\end{array}$ & 2019 & Conference & $\begin{array}{l}\text { General } \\
\text { description }\end{array}$ & SCM & Social acceptance, cost \\
\hline 103 & $\begin{array}{l}\text { Shou et al. } \\
\text { [12] }\end{array}$ & 2017 & Journal & $\begin{array}{l}\text { Expert } \\
\text { interview }\end{array}$ & $\begin{array}{l}\text { Contract management, SCM, } \\
\text { equipment leasing process }\end{array}$ & $\begin{array}{l}\text { Technical limitations, } \\
\text { construction industry inertia, } \\
\text { initial cost, lack of awareness }\end{array}$ \\
\hline 104 & $\begin{array}{l}\text { Zhang et al. } \\
\text { [22] }\end{array}$ & 2020 & Journal & $\begin{array}{l}\text { Framework } \\
\text { description }\end{array}$ & $\begin{array}{l}\text { Prefabricated component } \\
\text { quality traceability system }\end{array}$ & $\begin{array}{l}\text { unwillingness to accept, } \\
\text { information sharing, trust, } \\
\text { cost, one-off, technical } \\
\text { limitations }\end{array}$ \\
\hline
\end{tabular}


Table A1. Cont.

\begin{tabular}{|c|c|c|c|c|c|c|}
\hline \multirow{2}{*}{ No } & \multirow{2}{*}{ Authors } & \multirow{2}{*}{ Year } & \multirow{2}{*}{$\begin{array}{l}\text { Publication } \\
\text { Type }\end{array}$} & \multirow{2}{*}{ Methods } & \multicolumn{2}{|l|}{ Findings } \\
\hline & & & & & Benefits & Threats \\
\hline 105 & $\begin{array}{l}\text { Heiskanen } \\
{[67]}\end{array}$ & 2017 & Journal & $\begin{array}{l}\text { General } \\
\text { description }\end{array}$ & IoT + blockchain & \\
\hline 106 & $\begin{array}{l}\text { Dounas et al. } \\
{[69]}\end{array}$ & 2019 & Conference & $\begin{array}{l}\text { General } \\
\text { description }\end{array}$ & BIM + IoT + blockchain & \\
\hline 107 & $\begin{array}{l}\text { Siountri et al. } \\
{[68]}\end{array}$ & 2019 & Conference & $\begin{array}{l}\text { General } \\
\text { description }\end{array}$ & BIM + blockchain & Interoperability \\
\hline 108 & Li et al. [130] & 2021 & Journal & $\begin{array}{l}\text { Framework } \\
\text { description }\end{array}$ & $\begin{array}{l}\text { Off-site modular housing } \\
\text { production supervision }\end{array}$ & \\
\hline 109 & $\begin{array}{l}\text { Chaveesuk } \\
\text { et al. [39] }\end{array}$ & 2020 & Conference & $\begin{array}{l}\text { General } \\
\text { description }\end{array}$ & Stakeholder management & Coding of smart contracts \\
\hline 110 & $\begin{array}{l}\text { Sinenko and } \\
\text { Doroshin } \\
\text { [131] }\end{array}$ & 2020 & Conference & $\begin{array}{l}\text { General } \\
\text { description }\end{array}$ & Contract management & \\
\hline 111 & Shi et al. [37] & 2020 & Conference & $\begin{array}{l}\text { General } \\
\text { description }\end{array}$ & $\begin{array}{l}\text { Efficiency, transparency, } \\
\text { productivity, network security }\end{array}$ & \\
\hline 112 & Jo et al. [33] & 2018 & Journal & $\begin{array}{l}\text { General } \\
\text { description }\end{array}$ & IoT + blockchain & Security \\
\hline 113 & Lee et al. [70] & 2021 & Journal & $\begin{array}{l}\text { Framework } \\
\text { description }\end{array}$ & IoT + BIM + blockchain & Security \\
\hline 114 & Das et al. [71] & 2021 & Journal & $\begin{array}{l}\text { Literature } \\
\text { review }\end{array}$ & BIM + blockchain & \\
\hline 115 & $\begin{array}{l}\text { Parn and } \\
\text { Edwards [72] }\end{array}$ & 2019 & Journal & Case study & BIM + blockchain & $\begin{array}{l}\text { Application development and } \\
\text { testing }\end{array}$ \\
\hline 116 & $\begin{array}{l}\text { Gurgun and } \\
\text { Koc [132] }\end{array}$ & 2021 & Journal & AHP & Contract management & Stakeholder resistance \\
\hline
\end{tabular}

\section{References}

1. De Schepper, S.; Dooms, M.; Haezendonck, E. Stakeholder dynamics and responsibilities in Public-Private Partnerships: A mixed experience. Int. J. Proj. Manag. 2014, 32, 1210-1222. [CrossRef]

2. Luo, L.; Jin, X.; Shen, G.Q.; Wang, Y.; Liang, X.; Li, X.; Li, C.Z. Supply chain management for prefabricated building projects in Hong Kong. J. Manag. Eng. 2020, 36, 05020001. [CrossRef]

3. Luo, L.; Qiping Shen, G.; Xu, G.; Liu, Y.; Wang, Y. Stakeholder-associated supply chain risks and their interactions in a prefabricated building project in Hong Kong. J. Manag. Eng. 2019, 35, 05018015. [CrossRef]

4. Li, J.; Greenwood, D.; Kassem, M. Blockchain in the built environment and construction industry: A systematic review, conceptual models and practical use cases. Autom. Constr. 2019, 102, 288-307. [CrossRef]

5. Hunhevicz, J.J.; Hall, D.M. Do you need a blockchain in construction? Use case categories and decision framework for DLT design options. Adv. Eng. Inform. 2020, 45, 101094. [CrossRef]

6. Qian, X.; Papadonikolaki, E. Shifting trust in construction supply chains through blockchain technology. Eng. Constr. Archit. Manag. 2020, 28, 584-602. [CrossRef]

7. Wang, Z.; Wang, T.; Hu, H.; Gong, J.; Ren, X.; Xiao, Q. Blockchain-based framework for improving supply chain traceability and information sharing in precast construction. Autom. Constr. 2020, 111, 103063. [CrossRef]

8. Das, M.; Luo, H.; Cheng, J.C.P. Securing interim payments in construction projects through a blockchain-based framework. Autom. Constr. 2020, 118, 103284. [CrossRef]

9. Liu, Z.; Jiang, L.; Osmani, M.; Demian, P. Building information management (BIM) and blockchain (BC) for sustainable building design information management framework. Electronics 2019, 8, 724. [CrossRef]

10. Nawari, N.O.; Ravindran, S. Blockchain technologies in BIM workflow environment. In Computing in Civil Engineering 2019: Visualization, Information Modeling, and Simulation; American Society of Civil Engineers: Reston, VA, USA, 2019 ; pp. $343-352$.

11. Yang, R.; Wakefield, R.; Lyu, S.; Jayasuriya, S.; Han, F.; Yi, X.; Yang, X.; Amarasinghe, G.; Chen, S. Public and private blockchain in construction business process and information integration. Autom. Constr. 2020, 118, 103276. [CrossRef]

12. Wang, J.; Wu, P.; Wang, X.; Shou, W. The outlook of blockchain technology for construction engineering management. Front. Eng. Manag. 2017, 4, 67-75. [CrossRef] 
13. Dakhli, Z.; Lafhaj, Z.; Mossman, A. The potential of blockchain in building construction. Buildings 2019, 9, 77. [CrossRef]

14. San, K.M.; Choy, C.F.; Fung, W.P. The potentials and impacts of blockchain technology in construction industry: A literature review. In Proceedings of the IOP Conference Series: Materials Science and Engineering, Kazimierz Dolny, Poland, 21-23 November 2019.

15. Perera, S.; Nanayakkara, S.; Rodrigo, M.; Senaratne, S.; Weinand, R. Blockchain technology: Is it hype or real in the construction industry? J. Ind. Inf. Integr. 2020, 17, 100125. [CrossRef]

16. Pizzi, S.; Caputo, A.; Corvino, A.; Venturelli, A. Management research and the UN sustainable development goals (SDGs): A bibliometric investigation and systematic review. J. Clean. Prod. 2020, 276, 124033. [CrossRef]

17. Wallin, J.A. Bibliometric methods: Pitfalls and possibilities. Basic Clin. Pharmacol. Toxicol. 2005, 97, 261-275. [CrossRef] [PubMed]

18. Mayowa, I.A.; Joseph, H.L.; Edwin, H.C.; Amos, D. Heritage building maintenance management (HBMM): A bibliometricqualitative analysis of literature. J. Build. Eng. 2021, 42, 102416.

19. Van Eck, N.J.; Waltman, L.; Dekker, R.; van den Berg, J. A comparison of two techniques for bibliometric mapping: Multidimensional scaling and VOS. J. Am. Soc. Inf. Sci. Technol. 2010, 61, 2405-2416. [CrossRef]

20. Soust-Verdaguer, B.; Llatas, C.; García-Martínez, A. Critical review of bim-based LCA method to buildings. Energy Build. 2017. [CrossRef]

21. Wu, P.; Wang, J.; Wang, X. A critical review of the use of 3-D printing in the construction industry. Autom. Constr. 2016, 68, 21-31. [CrossRef]

22. Zhang, Z.; Yuan, Z.; Ni, G.; Lin, H.; Lu, Y. The quality traceability system for prefabricated buildings using blockchain: An integrated framework. Front. Eng. Manag. 2020, 7, 528-546. [CrossRef]

23. Sun, C.; Wang, M. Research on trust influence of building supply chain members based on blockchain technology. IOP Conf. Ser. Earth Environ. Sci. 2020, 525, 012019. [CrossRef]

24. De La Peña, J.; Papadonikolaki, E. From relational to technological trust: How do the IoT and blockchain technology fit in? In Proceedings of the 2019 European Conference on Computing in Construction (EC3), Crete, Greece, 10-12 July 2019 ; pp. 415-424.

25. Ahmadisheykhsarmast, S.; Sonmez, R. A smart contract system for security of payment of construction contracts. Autom. Constr. 2020, 120, 103401. [CrossRef]

26. Luo, H.; Das, M.; Wang, J.; Cheng, J.C.P. Construction payment automation through smart contract-based blockchain framework. In Proceedings of the 36th International Symposium on Automation and Robotics in Construction, ISARC 2019, Banff, AB, Canada, 21-24 May 2019; pp. 1254-1260.

27. Ye, X.; König, M. Framework for automated billing in the construction industry using BIM and smart contracts. In Proceedings of the International Conference on Computing in Civil and Building Engineering, São Paulo, Brazil, 18-20 August 2020; pp. 824-838.

28. Chong, H.-Y.; Diamantopoulos, A. Integrating advanced technologies to uphold security of payment: Data flow diagram. Autom. Constr. 2020, 114, 103158. [CrossRef]

29. Shojaei, A. Exploring applications of blockchain technology in the construction industry. In Proceedings of the ISEC 2019-10th International Structural Engineering and Construction Conference, Chicago, IL, USA, 20-25 May 2019.

30. Turk, Ž.; Klinc, R. Potentials of blockchain technology for construction management. Procedia Eng. 2017, 196, 638-645. [CrossRef]

31. Li, J.; Kassem, M.; Watson, R. A blockchain and smart contract-based framework to increase traceability of built assets. In Proceedings of the 37th CIB W78 Information Technology for Construction Conference, São Paulo, Brazil, 18-20 August 2020.

32. Amaludin, A.; Bin Taharin, M. Prospect of blockchain technology for construction project management in Malaysia. ASM Sci. J. 2018, 11, 199-205.

33. Jo, B.W.; Khan, R.M.A.; Lee, Y.-S. Hybrid blockchain and internet-of-things network for underground structure health monitoring. Sensors 2018, 18, 4268. [CrossRef] [PubMed]

34. Sheng, D.; Ding, L.; Zhong, B.; Love, P.E.; Luo, H.; Chen, J. Construction quality information management with blockchains. Autom. Constr. 2020, 120, 103373. [CrossRef]

35. Zhong, B.; Wu, H.; Ding, L.; Luo, H.; Luo, Y.; Pan, X. Hyperledger fabric-based consortium blockchain for construction quality information management. Front. Eng. Manag. 2020, 7, 512-527. [CrossRef]

36. Goh, K.C.; Teoh, T.Y.; Goh, H.H.; Bilal, K.; Chai, C.S. Blockchain potentials in enhancing construction stakeholders collaboration. Malays. Constr. Res. J. 2019, 7, 177-189.

37. Shi, M.; Hoffmann, A.; Wagner, A.; Huyeng, T.; Thiele, C.-D.; Rüppel, U. Using blockchain technology to implement Peer-to-Peer network in construction industry. In Proceedings of the International Conference on Computing in Civil and Building Engineering, São Paulo, Brazil, 18-20 August 2020; pp. 839-849.

38. Nanayakkara, S.; Perera, S.; Senaratne, S. Stakeholders' perspective on blockchain and smart contracts solutions for construction supply chains. In Proceedings of the CIB World Building Congress, Hong Kong, China, 17-21 June 2019.

39. Chaveesuk, S.; Khalid, B.; Chaiyasoonthorn, W. Understanding stakeholders needs for using blockchain based smart contracts in construction industry of Thailand: Extended TAM framework. In Proceedings of the 2020 13th International Conference on Human System Interaction (HSI), Tokyo, Japan, 6-8 June 2020; pp. 137-141.

40. Mason, J.; Escott, H. Smart contracts in construction: Views and perceptions of stakeholders. In Proceedings of the FIG Conference, Istanbul, Turkey, 6-11 May 2018.

41. Xue, F.; Lu, W. A semantic differential transaction approach to minimizing information redundancy for BIM and blockchain integration. Autom. Constr. 2020, 118, 103270. [CrossRef] 
42. Lokshina, I.V.; Greguš, M.; Thomas, W.L. Application of integrated building information modeling, IoT and blockchain technologies in system design of a smart building. Procedia Comput. Sci. 2019, 160, 497-502. [CrossRef]

43. Mathews, M.; Robles, D.; Bowe, B. BIM+ blockchain: A solution to the trust problem in collaboration? In Proceedings of the CITA BIM Gathering 2017, Dublin, Ireland, 23-24 November 2017.

44. Dounas, T.; Lombardi, D. A CAD-blockchain integration strategy for distributed validated digital design-connecting the blockchain. In Proceedings of the 36th eCAADe Conference, Lodz, Poland, 17-21 September 2018.

45. Li, J.; Kassem, M.; Ciribini, A.; Bolpagni, M. A proposed approach integrating DLT, BIM, IOT and smart contracts: Demonstration using a simulated installation task. In Proceedings of the International Conference on Smart Infrastructure and Construction 2019 (ICSIC) Driving Data-Informed Decision-Making, Cambridge, UK, 8-10 July 2019; pp. 275-282.

46. Shojaei, A.; Flood, I.; Moud, H.I.; Hatami, M.; Zhang, X. An implementation of smart contracts by integrating BIM and blockchain. In Proceedings of the Future Technologies Conference (FTC) 2019; Advances in Intelligent Systems and Computing; Springer: Cham, Switzerland, 2020; pp. 519-527.

47. Wei, Y.; Cui, E. Application of blockchain and big data technology in the safety information management of architecture employees. In Proceedings of the IOP Conference Series: Earth and Environmental Science, Changchun, China, 21-23 August 2020; p. 012042.

48. Ilin, I.; Lanko, A.; Vatin, N.; Kaklauskas, A.; Kalinina, O. Application of RFID combined with blockchain technology in logistics of construction materials. In Proceedings of the MATEC Web of Conferences, St. Petersburg, Russia, 20-22 December 2017; p. 03032.

49. Zheng, R.; Jiang, J.; Hao, X.; Ren, W.; Xiong, F.; Ren, Y. bcBIM: A blockchain-based big data model for BIM modification audit and provenance in mobile cloud. Math. Probl. Eng. 2019, 2019, 1-13. [CrossRef]

50. Mason, J. BIM fork: Are smart contracts in construction more likely to prosper with or without BIM? J. Leg. Aff. Disput. Resolut. Eng. Constr. 2019, 11, 02519002. [CrossRef]

51. Singh, P. Blockchain based security solutions with IoT application in construction industry. In Proceedings of the IOP Conference Series: Earth and Environmental Science, Tashkent, Uzbekistan, 14-16 October 2020; p. 012052.

52. Chew, A. Blockchain in construction-it's all about data, trust and productivity. Gov. Dir. 2019, 71, 333-337.

53. Ye, Z.; Yin, M.; Tang, L.; Jiang, H. Cup-of-Water theory: A review on the interaction of BIM, IoT and blockchain during the whole building lifecycle. In Proceedings of the ISARC 2018-35th International Symposium on Automation and Robotics in Construction and International AEC/FM Hackathon: The Future of Building Things, Berlin, Germany, 20-25 July 2018.

54. Siountri, K.; Skondras, E.; Vergados, D.D. Developing smart buildings using blockchain, Internet of Things, and building information modeling. Int. J. Interdiscip. Telecommun. Netw. 2020, 12, 1-15. [CrossRef]

55. Pellegrini, L.; Campi, S.; Locatelli, M.; Pattini, G.; Di Giuda, G.M.; Tagliabue, L.C. Digital transition and waste management in architecture, engineering, construction, and operations industry. Front. Energy Res. 2020, 8, 282. [CrossRef]

56. Shinde, R.; Nilakhe, O.; Pondkule, P.; Karche, D.; Shendage, P. Enhanced road construction process with machine learning and blockchain technology. In Proceedings of the 2020 International Conference on Industry 4.0 Technology, I4Tech 2020, Pune, India, 13-15 February 2020; pp. 207-210.

57. Dounas, T.; Lombardi, D.; Jabi, W. Framework for decentralised architectural design BIM and blockchain integration. Int. J. Archit. Comput. 2021, 19, 157-173.

58. O'Reilly, A.; Mathews, M. Incentivising multidisciplinary teams with new methods of procurement using BIM+ blockchain. In Proceedings of the CITA BIM Gathering 2019, Galway, Ireland, 26 September 2019.

59. Safa, M.; Baeza, S.; Weeks, K. Incorporating blockchain technology in construction management. Strateg. Dir. 2019, 35, 1-3. [CrossRef]

60. Elghaish, F.; Abrishami, S.; Hosseini, M.R. Integrated project delivery with blockchain: An automated financial system. Autom. Constr. 2020, 114, 103182. [CrossRef]

61. Hill, A. PhD forum abstract: Transforming construction processes using internet of things and blockchain. In Proceedings of the 2020 19th ACM/IEEE International Conference on Information Processing in Sensor Networks, IPSN 2020, Sydney, Australia, 21-24 April 2020; pp. 383-384.

62. Dounas, T.; Jabi, W.; Lombardi, D. Smart contracts for decentralised building information modelling. In Proceedings of the 38th Education and Research in Computer Aided Architectural Design in Europe (eCAADe) Conference 2020 (eCAADe 2020), Online Conference, 16-17 September 2020; pp. 565-574.

63. Cardeira, H. Smart contracts and possible applications to the construction industry. In Proceedings of the New Perspectives in Construction Law Conference, Bucharest, Romania, 19-21 March 2015.

64. Di Giuda, G.M.; Pattini, G.; Seghezzi, E.; Schievano, M.; Paleari, F. The construction contract execution through the integration of blockchain technology. In Digital Transformation of the Design, Construction and Management Processes of the Built Environment; Springer: Cham, Switzerland, 2020; pp. 27-36.

65. Li, W.; Duan, P.; Su, J. The effectiveness of project management construction with data mining and blockchain consensus. J. Ambient Intell. Humaniz. Comput. 2021, 1-10. [CrossRef]

66. Hargaden, V.; Papakostas, N.; Newell, A.; Khavia, A.; Scanlon, A. The role of blockchain technologies in construction engineering project management. In Proceedings of the 2019 IEEE International Conference on Engineering, Technology and Innovation (ICE/ITMC), Valbonne, France, 17-19 August 2019; pp. 1-6. 
67. Heiskanen, A. The technology of trust: How the Internet of Things and blockchain could usher in a new era of construction productivity. Constr. Res. Innov. 2017, 8, 66-70. [CrossRef]

68. Siountri, K.; Skondras, E.; Vergados, D.D. Towards a smart museum using BIM, IoT, blockchain and advanced digital technologies. In Proceedings of the ACM International Conference Proceeding Series, New York, NY, USA, 26-28 August 2019.

69. Dounas, T.; Lombardi, D.; Jabi, W. Towards blockchains for architectural design-consensus mechanisms for collaboration in BIM. In Proceedings of the 37th eCAADe and 23rd SIGraDi Conference, Porto, Portugal, 11-13 September 2019; pp. $267-274$.

70. Lee, D.; Lee, S.H.; Masoud, N.; Krishnan, M.; Li, V.C. Integrated digital twin and blockchain framework to support accountable information sharing in construction projects. Autom. Constr. 2021, 127, 103688. [CrossRef]

71. Das, M.; Tao, X.; Cheng, J.C. BIM security: A critical review and recommendations using encryption strategy and blockchain. Autom. Constr. 2021, 126, 103682. [CrossRef]

72. Parn, E.A.; Edwards, D. Cyber threats confronting the digital built environment: Common data environment vulnerabilities and block chain deterrence. Eng. Constr. Archit. Manag. 2019, 1, 267-274. [CrossRef]

73. Kiu, M.S.; Chia, F.C.; Wong, P.F. Exploring the potentials of blockchain application in construction industry: A systematic review. Int. J. Constr. Manag. 2020, 2020, 1-10. [CrossRef]

74. Tezel, A.; Papadonikolaki, E.; Yitmen, I.; Hilletofth, P. Preparing construction supply chains for blockchain technology: An investigation of its potential and future directions. Front. Eng. Manag. 2020, 7, 547-563. [CrossRef]

75. Hamledari, H.; Fischer, M. Role of blockchain-enabled smart contracts in automating construction progress payments. J. Leg. Aff. Disput. Resolut. Eng. Constr. 2021, 13, 04520038. [CrossRef]

76. Hijazi, A.A.; Perera, S.; Alashwal, A.; Calheiros, R.N. Blockchain adoption in construction supply chain: A review of studies across multiple sectors. In Proceedings of the CIB World Building Congress, Hong Kong, China, 17-21 June 2019.

77. Kifokeris, D.; Koch, C. Blockchain in construction logistics: State-of-art, constructability, and the advent of a new digital business model in Sweden. In Proceedings of the 2019 European Conference on Computing in Construction, Crete, Greece, 10-12 July 2019; pp. 332-340.

78. McNamara, A.; Sepasgozar, S. Barriers and drivers of intelligent contract implementation in construction. Management 2018, 143, 02517006.

79. Sharma, M.G.; Kumar, S. The implication of blockchain as a disruptive technology for construction industry. IIM Kozhikode Soc. Manag. Rev. 2020, 9, 177-188. [CrossRef]

80. Pattini, G.; Giuda, G.M.D.; Tagliabue, L.C. Blockchain application for contract schemes in the construction industry. In Proceedings of the 3rd European and Mediterranean Structural Engineering and Construction Conference 2020, Euro-Med-Sec 2020, Limassol, Cyprus, 3-8 August 2020; pp. 1-6.

81. Kifokeris, D.; Koch, C. A conceptual digital business model for construction logistics consultants, featuring a sociomaterial blockchain solution for integrated economic, material and information flows. J. Inf. Technol. Constr. 2020, 25, 500-521. [CrossRef]

82. Khan, A.-N.; Iqbal, N.; Rizwan, A.; Ahmad, R.; Kim, D.-H. An ensemble energy consumption forecasting model based on spatial-temporal clustering analysis in residential buildings. Energies 2021, 14, 3020. [CrossRef]

83. Khan, A.N.; Iqbal, N.; Ahmad, R.; Kim, D.-H. Ensemble prediction approach based on learning to statistical model for efficient building energy consumption management. Symmetry 2021, 13, 405. [CrossRef]

84. Jamil, F.; Iqbal, N.; Ahmad, S.; Kim, D. Peer-to-Peer energy trading mechanism based on blockchain and machine learning for sustainable electrical power supply in smart grid. IEEE Access 2021, 9, 39193-39217. [CrossRef]

85. Lin, X.; McKenna, B.; Ho, C.M.; Shen, G.Q. Stakeholders' influence strategies on social responsibility implementation in construction projects. J. Clean. Prod. 2019, 235, 348-358. [CrossRef]

86. Olander, S.; Landin, A. Evaluation of stakeholder influence in the implementation of construction projects. Int. J. Proj. Manag. 2005, 23, 321-328. [CrossRef]

87. Lee, Z.; Rahman, R.; Doh, S. Key drivers for adopting design build: A comparative study between project stakeholders. Phys. Chem. Earth Parts A/B/C 2020, 120, 102945. [CrossRef]

88. Xiong, F.; Xiao, R.; Ren, W.; Zheng, R.; Jiang, J. A key protection scheme based on secret sharing for blockchain-based construction supply chain system. IEEE Access 2019, 7, 126773-126786. [CrossRef]

89. Das, M.; Tao, X.; Cheng, J.C.P. A secure and distributed construction document management system using blockchain. Lect. Notes Civ. Eng. 2021, 98, 850-862.

90. Kim, K.; Lee, G.; Kim, S. A study on the application of blockchain technology in the construction industry. KSCE J. Civ. Eng. 2020, 24, 2561-2571. [CrossRef]

91. Owusu, E.K.; Chan, A.P.C.; Nani, G.; Agymang, D.Y. A turn to smart contracts and future applications towards construction innovation: A hybrid-metric review. In Proceedings of the Construction Research Congress 2020: Computer ApplicationsSelected Papers from the Construction Research Congress 2020, Tempe, Arizona, 8-10 March 2020; pp. $246-257$.

92. Fitriawijaya, A.; Hsin-Hsuan, T.; Taysheng, J. A blockchain approach to supply chain management in a BIM-enabled environment. In Proceedings of the Intelligent and Informed-Proceedings of the 24th International Conference on Computer-Aided Architectural Design Research in Asia, CAADRIA 2019, Nanjing, China, 14-19 April 2019; pp. 411-420.

93. Li, C.Z.; Chen, Z.; Xue, F.; Kong, X.T.R.; Xiao, B.; Lai, X.; Zhao, Y. A blockchain- and IoT-based smart product-service system for the sustainability of prefabricated housing construction. J. Clean. Prod. 2021, 286, 125391. [CrossRef] 
94. Danielle, N. Allocation of risk in public private partnerships in information and communications technology. Int. J. Ebus. Egov. Stud. 2020, 12, 17-32.

95. Raslan, A.; Kapogiannis, G.; Cheshmehzangi, A.; Tizani, W.; Towey, D. Blockchain: Future facilitator of asset information modelling and management? In Proceedings of the 2020 IEEE 44th Annual Computers, Software, and Applications Conference (COMPSAC), Madrid, Spain, 13-17 July 2020; pp. 523-528.

96. Nawari, N.; Ravindran, S. Blockchain and building information modeling (BIM): Review and applications in post-disaster recovery. Buildings 2019, 9, 149. [CrossRef]

97. Nawari, N.O.; Ravindran, S. Blockchain and the built environment: Potentials and limitations. J. Build. Eng. 2019, $25,100832$. [CrossRef]

98. Shemov, G.; Garcia de Soto, B.; Alkhzaimi, H. Blockchain applied to the construction supply chain: A case study with threat model. Front. Eng. Manag. 2020, 7, 564-577. [CrossRef]

99. Rodrigo, M.N.; Perera, S.; Senaratne, S.; Jin, X. Blockchain for construction supply chains: A literature synthesis. In Proceedings of the ICEC-PAQS Conference 2018, Sydney, Australia, 18-20 November 2018.

100. Kifokeris, D.; Koch, C. Blockchain in building logistics: Emerging knowledge, and related actors in Sweden. In Proceedings of the Association of Researchers in Construction Management, ARCOM 2019_Proceedings of the 35th Annual Conference, Leeds, UK, 2-4 September 2019; pp. 426-435.

101. Hamma-adama, M.; Salman, H.; Kouider, T. Blockchain in construction industry: Challenges and opportunities. In Proceedings of the 2020 International Engineering Conference and Exhibition (IECE 2020), Riyadh, Saudi Arabia, 2-5 March 2020.

102. Sivula, A.; Shamsuzzoha, A.; Helo, P. Blockchain in logistics: Mapping the opportunities in con-struction industry. In Proceedings of the International Conference on Industrial Engineering and Operations Management, Bandung, Indonesia, 6-8 March 2018; pp. 1954-1960.

103. Li, J.; Greenwood, D.; Kassem, M. Blockchain in the construction sector: A socio-technical systems framework for the construction industry. In Advances in Informatics and Computing in Civil and Construction Engineering; Springer: Cham, Switzerland, 2019; pp. 51-57.

104. Kassem, M.; Lia, J.; Greenwood, D. Blockchain in the built environment: Analysing current applications and developing an emergent framework. In Proceedings of the Creative Construction Conference 2018-Proceedings, Ljubljana, Slovenia, 30 June-3 July 2018; pp. 59-66.

105. Nawari, N.O.; Ravindran, S. Blockchain technology and BIM process: Review and potential applications. J. Inf. Technol. Constr. 2019, 24, 209-238.

106. Nanayakkara, S.; Perera, S.; Bandara, H.D.; Weerasuriya, G.T.; Ayoub, J. Blockchain technology and its potential for the construction industry. In Proceedings of the AUBEA Conference, Noosa, Australia, 6-8 November 2019; pp. 662-672.

107. Hewavitharana, T.; Nanayakkara, S.; Perera, S. Blockchain as a project management platform. In Proceedings of the 8th World Construction Symposium, Colombo, Sri Lanka, 8-10 November 2019; pp. 137-146.

108. Boonpheng, A.; Kongsong, W.; Usahanunth, N.; Pooworakulchai, C. Bringing blockchain technology to construction engineering management. Int. J. Eng. Res. Technol. 2020, 9, 172-177.

109. Chen, C.; Ren, H.; Zhang, L. Construction and empirical analysis of information management system of engineering investigation quality. In Proceedings of the Journal of Physics: Conference Series, Moscow, Russia, 5-9 October 2020; p. 012038.

110. Adibfar, A.; Costin, A.; Issa, R.R. Design copyright in architecture, engineering, and construction industry: Review of history, pitfalls, and lessons learned. J. Leg. Aff. Disput. Resolut. Eng. Constr. 2020, 12, 04520032. [CrossRef]

111. McNamara, A.J.; Sepasgozar, S.M.E. Developing a theoretical framework for intelligent contract acceptance. Constr. Innov. 2020, 20, 421-445. [CrossRef]

112. Prakash, A.; Ambekar, S. Digital transformation using blockchain technology in the construction industry. J. Inf. Technol. Case Appl. Res. 2020, 22, 256-278.

113. Graham, S.; Hailer, J.D. Implementation of blockchain technology in the construction industry. In Proceedings of the Annual Conference-Canadian Society for Civil Engineering, Sherbrooke, QC, Canada, 5-7 August 2019.

114. Li, J.; Kassem, M. Informing implementation of distributed ledger technology (DLT) in construction: Interviews with industry and academia. In Proceedings of the 36th CIB W78 Conference in ICT in Design, Construction and Management in Architecture, Engineering, Construction and Operations (AECO), Newcastle, UK, 18-20 September 2019; Volume 78.

115. Mason, J. Intelligent contracts and the construction industry. J. Leg. Aff. Disput. Resolut. Eng. Constr. 2017, 9, 04517012. [CrossRef]

116. McNamara, A.J.; Sepasgozar, S.M. Intelligent contract adoption in the construction industry: Concept development. Autom. Constr. 2021, 122, 103452. [CrossRef]

117. Singh, S.; Ashuri, B. Leveraging blockchain technology in AEC industry during design development phase. In Computing in Civil Engineering 2019: Visualization, Information Modeling, and Simulation; American Society of Civil Engineers: Reston, VA, USA, 2019; pp. 393-401.

118. Erri Pradeep, A.S.; Yiu, T.W.; Amor, R. Leveraging blockchain technology in a BIM workflow: A literature review. In Proceedings of the International Conference on Smart Infrastructure and Construction 2019, ICSIC 2019: Driving Data-Informed DecisionMaking, Cambridge, UK, 8-10 July 2019; pp. 371-380.

119. Hunhevicz, J.J.; Hall, D.M. Managing mistrust in construction using DLT: A review of use-case categories for technical decisions. In Proceedings of the 2019 European Conference on Computing in Construction, Crete, Greece, 10-12 July 2019; pp. 100-109. 
120. Rodrigo, M.N.N.; Perera, S.; Senaratne, S.; Jin, X. Potential application of blockchain technology for embodied carbon estimating in construction supply chains. Buildings 2020, 10, 140. [CrossRef]

121. Tezel, A.; Papadonikolaki, E.; Yitmen, I.; Hilletofth, P. Preparing construction supply chains for blockchain: An exploratory analysis. In Proceedings of the CIB World Building Congress 2019 Constructing Smart Cities, Hong Kong, China, 17-21 June 2019.

122. Abrishami, S.; Elghaish, F. Revolutionising AEC financial system within project delivery stages: A permissioned blockchain digitalised framework. In Proceedings of the 36th CIB W78, Melbourne, Australia, 27-30 June 2019.

123. Darabseh, M.; Martins, J.P. Risks and opportunities for reforming construction with blockchain: Bibliometric study. Civ. Eng. J. 2020, 6, 1204-1217. [CrossRef]

124. Faraji, A. Smart contract based conceptual model for optimizing risk distribution in construction industry. In Proceedings of the 3rd International Conference on Applied Researches in Structual Engineering and Construction Management, Tehran, Iran, 26-27 June 2019; pp. 1-10.

125. Ahmadisheykhsarmast, S.; Sonmez, R. Smart contracts in construction industry. In Proceedings of the 5th International Project \& Construction Management Conference, Nicosia, Cyprus, 16-18 November 2018; pp. 767-774.

126. Badi, S.; Ochieng, E.; Nasaj, M.; Papadaki, M. Technological, organisational and environmental determinants of smart contracts adoption: UK construction sector viewpoint. Constr. Manag. Econ. 2021, 39, 36-54. [CrossRef]

127. Belle, I. The architecture, engineering and construction industry and blockchain technology. Digit. Cult. 2017, 2017, 279-284.

128. Cardeira, H. The benefits of integrating smart contracts and BIM during construction. Rom. Constr. Law Rev. 2017, 2, 35-38.

129. Qian, X.; Papadonikolaki, E. The Influence of the blockchain technology on trust in construction supply chain management. In Proceedings of the 2019 CIB International Council for Research and Innovation in Building and Construction Conference, Hong Kong, China, 17-21 June 2019.

130. Li, X.; Wu, L.; Zhao, R.; Lu, W.; Xue, F. Two-layer adaptive blockchain-based supervision model for off-site modular housing production. Comput. Ind. 2021, 128, 103437. [CrossRef]

131. Sinenko, S.A.; Doroshin, I.N. Use of modern means and methods in the organization and management in construction. In Proceedings of the IOP Conference Series: Materials Science and Engineering, Chennai, India, 16-17 September 2020.

132. Gurgun, A.P.; Koc, K. Administrative Risks Challenging the Adoption of Smart Contracts in Construction Projects. Available online: http:/ /URL/10.1108/ECAM-09-2020-0678/ (accessed on 30 March 2021). 